Frans Plank and Aditi Lahiri

\title{
Macroscopic and microscopic typology: Basic Valence Orientation, more pertinacious than meets the naked eye
}

\begin{abstract}
Basic Valence Orientation has been suggested as a typological parameter by Nichols, Peterson, \& Barnes (2004). Generalising over the entire lexicon, the idea is that languages can be distinguished as transitivising or detransitivising, depending on whether their verbs are basically intransitive or transitive and the opposite valency values require some means of derivation, such as causativisation or decausativisation. Whereas derivedness among valency opposites is assessed through easy-to-spot overt segmental morphological or syntactic markers by Nichols et al. (2004), we argue that PHONOLOGICAL alternations, on their own or attendant upon conjugation class switches between intransitives and transitives, can be as directed as derivations are which are implemented through adding segmental markers. Illustrating from German, we show that stem vowel patterns in strong and corresponding weak verbs (with the former expressing inflectional categories through ablaut) as well as umlaut alternations in verb derivation are systematically involved in valency oppositions and are both directed. Thus, German emerges as being typologically mixed, being strongly transitivising on the grounds of such asymmetric formal patterns, while also showing (as observed by Nichols et al. 2004) a detransitivising or indeterminate disposition through syntactic "middle" marking or verb lability. This typological result is also of diachronic significance, insofar as the older transitivising inclination is seen to have been remarkably pertinacious, long surviving the loss of the affixal valencyincreasing morphology of Common Germanic and able to hold its own against more recent detransitivising competition.
\end{abstract}

Keywords: argument structure, causative, decausative, derivation, German, inflection classes, lexicon, morphology, syntax, time stability, transitivity

DOI 10.1515/lingty-2015-0001

Received September 5, 2011; revised January 31, 2015

Frans Plank, Sprachwissenschaft, Universität Konstanz, 78457 Konstanz, Germany; Somerville College, Oxford OX2 6HD, England, E-mail: frans.plank@uni-konstanz.de;

frans.plank@ling-phil.ox.ac.uk

Aditi Lahiri, Faculty of Linguistics, Philology and Phonetics, University of Oxford, Walton Street, Oxford OX1 2HG, England, E-mail: aditi.lahiri@ling-phil.ox.ac.uk 


\section{Typology: Macro and micro}

Typology is the search for order in the diversity of lexicons and grammars, with unity (same as all others) and uniqueness (different from all others) as the opposite extremes. Limitations of diversity, as discovered through crosslinguistic comparison, then, may be a matter of chance or necessity. That is, such limitations may reflect the contingencies of human population history, and as such would be of no genuinely linguistic concern. Or, on the side of necessity (be it linguistic, more generally cognitive, or social), they may reflect constraints on those parts of human bodies and minds that are linguistically active or constraints on the transmission of linguistic know-how across generations. Teasing apart chance and necessity is a formidable challenge, no less exacting than the charting of diversity and the inductive identification of its limits in the first place. Yet, to be able to meet it, typological research methodology must be targeted at both, historical contingencies on the one hand and mental lexiconsand-grammars and their social transmission on the other. Our general concern in this article is with getting the right take on constraints on mental lexicons in their interaction with grammar.

When typological research is based on large language samples, there tend to be certain preferred structural focuses for charting diversity and inducing unity. Typological generalisations are commonly sought for patterns of contrasts, paradigmatic or syntagmatic, which can be readily recognised from concrete surface forms and their distributions. Such patterns, with their conventional categorial labels, can be gleaned at a glance from descriptive grammars and dictionaries or from smallish text corpora, and are none-too-intricate to elicit through questionnaires, the typical sources of information for sample-based typology. Patterns which only emerge through probing in-depth analysis, and which may involve abstract rather than only concrete structures, tend to be neglected, because this is something which few descriptive grammars and dictionaries let themselves in for and which would threaten to overburden questionnaires. Perhaps sampling typologists also favour concrete over abstract structures as a matter of descriptive principle, informed by the theoretical models of their choice. Or such neglect may have the purely practical reason that the familiarity with lexical-grammatical intricacies required here is unattainable for the scores of languages in one's sample.

The resulting dilemma is that constraints identified through typological research, typically taking the form of implications constraining co-variation among variables (or co-evolution if the perspective is diachronic), are often hard to interpret as constraints on mental lexicons-and-grammars or their social 
transmission: concrete, analytically shallow typological variables do not readily translate into constructs of mental lexicons-and-grammars or learning processes, however these are conceived of by neuropsychologists. If there is little awareness of typological research results in neuroscience despite all its concern with language, there is also a reluctance on the part of typology to go mental.

To bridge the gap between width of crosslinguistic coverage and depth of structural analysis in typological research, it is therefore advisable to seek to complement "descriptive", macroscopic typology through more "analytic", microscopic typology. This is what we propose to do here for a potentially major typological parameter concerning the interface of lexicon and syntax suggested by Nichols, Peterson, \& Barnes (2004), BASIC VALENCE ORIENTATION. Our microscope will be trained on asymmetries in valency pairs whose typological significance has not been properly appreciated, because it is only through abstract representations that the formal oppositions involved are recognised as not symmetric.

\section{Basic Valence Orientation}

\subsection{The typological parameter}

Based on a comparative study of 18 verb pairs, or rather of pairs of meanings expressed through verbs or other predicates (adjectives, nouns), across a genealogically and areally diversified sample of 80 languages, Nichols et al. (2004) suggest BASIC or LEXICAL VALENCE ORIENTATION as a typological parameter - something where languages differ rather than all being the same. The claim they make is a strong one: it is that languages differ, not word by word, but in the valence orientation of their entire verbal vocabulary. Accordingly, verbs in toto, or in their overwhelming majority, will either be lexically intransitive, with corresponding transitive or ditransitive verbs (causatives, factitives, and such) being derived, or they will all or overwhelmingly be lexically transitive or ditransitive, with verbs of lower transitivity (decausatives, inchoatives, statives, and such) being derived. The typological distinction postulated is thus one of TRANSITIVISING vs. DETRANSITIVISING LANGUAGES. Ideally this could be a categorical distinction, but in reality it will be more in the nature of a cline.

These were the pairs of verbal meanings examined, as exemplars representative of verbal vocabulary in general: 
(1)

\begin{tabular}{|c|c|c|}
\hline \multirow{20}{*}{ or: } & VALENCY $n$ & VALENCY $n+1$ \\
\hline & VALENCY $n-1$ & VALENCY $n$ \\
\hline & 'laugh' & 'make laugh, amuse' \\
\hline & ‘die’ & 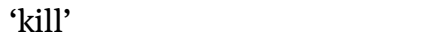 \\
\hline & 'sit' & 'seat, make sit' \\
\hline & 'eat' & 'feed, give food' \\
\hline & 'learn, know' & 'teach' \\
\hline & 'see’ & 'show' \\
\hline & 'be, become angry' & 'make angry' \\
\hline & ‘fear, be afraid’ & 'frighten, scare' \\
\hline & 'be in, go into hiding' & 'conceal, put into hiding' \\
\hline & '(come to) boil’' & '(bring to) boil’' \\
\hline & 'be on, catch fire’' & 'set on fire' \\
\hline & 'break (come apart)’ & 'break (cause to come apart)' \\
\hline & '(be, become) open’ & '(cause to be, become) open' \\
\hline & ‘dry' & 'make dry' \\
\hline & 'be/become straight' & 'straighten, make straight' \\
\hline & 'hang' & 'hang (up)' \\
\hline & 'turn over' & '(cause to) turn over' \\
\hline & 'fall' & 'drop, let fall' \\
\hline
\end{tabular}

Subset (1a) of this diagnostic list includes verbs whose sole argument, or the subject argument in the lower-valency construction which may itself involve an object, tends to be animate, while the verbs in subset (1b) tend to have inanimate subject arguments in the lower-valency construction. What Nichols et al. find is that inanimate-argument verbs (subset (1b)) tend to be basically transitive across languages. It is only when they are transitive that they have an agent argument, referring to a human or other animate or some causal force - and it is assumed as a universal tendency that states or actions involving animates are lexicalised as basic (Nichols et al. 2004: 172). ${ }^{1}$ It is primarily with animateargument verbs (subset (1a)), where animates are involved in вотн lower-valency and higher-valency constructions and the competition is therefore undecided, that a typological difference is observed between the lower-valency or the higher-valency meaning as the language-particular preference for lexical and syntactic basicness. Still, transitivisation is considered a typologically marked state of affairs vis-à-vis more common detransitivisation.

1 Elsewhere other lines and rationales for subdividing the verbal vocabulary have been assumed to be more revealing of typological differences or indeed of universal patterns of directionality in derivation; see Section 6. 
There are several formal ways of being derived - valency-augmented in the case of transitivisation vs. valency-reduced in the case of detransitivisation - in the sense of that study:

(i) verb-to-verb-deriving affixation (or also adjective-to-verb- or noun-to-verbderiving);

(ii) addition of non-morphological segmental material such as particles or middle/reflexive markers;

(iii) phonological alternation (such as ablaut or umlaut);

(iv) change of conjugation class;

(v) change of auxiliary or light verb (where such elements are exploited for valency alternation).

It was for practical reasons that conjugation class and auxiliary or light verb alternations as well as phonological alternations were not taken into account by Nichols et al. Admitting that there may be grounds (perhaps historical) for seeing one alternant as basic and the other as derived, it was found impracticable, in view of the wide range of languages in the sample, to determine directionality for synchronic grammar (and from synchronic descriptive grammars and dictionaries or from elicitation questionnaires). Two formal kinds of alternations, on the other hand, were recognised as INHERENTLY non-directional: suppletion (as in English learn - teach) and "ambitransitivity", the use of the same verb for both valency opposites (e.g., English boil - boil). ${ }^{2}$ Given such practical and inherent difficulties with directionality, languages were typologised not only as transitivising or detransitivising, but also as INDETERMINATE when there were no (macroscopically) recognisable basic-derived differences between the members of correspondence pairs examined. A further type, NEUTRAL, accommodates such languages where both lower-valency and higher-valency meanings are manifestly derived.

Nichols et al. (2004) is an exercise in lexical typology which is unprecedented in crosslinguistic scale and rigour. ${ }^{3}$ However, there are inherent

2 A precursor study, Haspelmath (1993), had proceeded analogously, and similarly Comrie (2006) and Cysouw (2008, 2010), who took things further: the causative-anticausative alternation was only recognised as directed when one or the other partner carried extra segmental marking. The alternation was considered non-directed in the case of "labile" verbs ("ambitransitive” for Nichols et al.), "equipollent” verbs (different forms, but not tangibly differing in one or the other having more or less overt marking), and suppletive verbs.

3 Nedjalkov (1969), Nichols (1982), and Haspelmath (1993) are acknowledged as precursors, although these earlier studies were lexically and typologically less extensive. Similar wholelanguage typologies of preferred lexicalisation patterns have also been postulated in work of Leonard Talmy, and one of his lexical-typological parameters concerns the incorporation or non-incorporation of various kinds of causative senses (such as "resulting-event", 
limitations of the macroscopic approach that this study epitomises. There are significant patterns which are not easy to see at a glance from contrasts between concrete forms, as recorded in descriptive grammars and dictionaries and as readily elicited through questionnaires, and to recognise these it needs as it were a microscope - in-depth structural analysis, accompanied by textual exegesis and experimental psycholinguistic testing for representations and processes in the mental lexicon.

\subsection{Typologising German}

In Nichols et al. (2004: 189, 193), German is classified as detransitivising for animate-argument verbs (1a), the assumed frontline of typological battle, and as indeterminate for typologically less disputed inanimate-argument verbs (1b). Although German is not one of the languages for which decisions are illustrated and justified in detail, this typological classification will crucially have been based on the possibility, shared with many other languages, of detransitivisation through "middle" constructions for many transitive verbs, including perhaps one third on the list of 18 of Nichols et al.:

(2)

\section{INTRANSITIVE}

a. sich setzen 'take a seat'

sich ärgern 'be/become angry'

sich amüsieren 'enjoy oneself'

(sich) erschrecken 'fear, be frightened'

sich verstecken 'hide oneself, go into hiding'

b. (sich) öffnen 'become open'

(sich) (um-)drehen 'turn over/around' $\leftarrow$ TRANSITIVE

setzen 'set'

ärgern 'annoy'

amüsieren 'amuse'

erschrecken 'frighten'

verstecken 'hide'

öffnen 'cause to become open'

(um-)drehen 'cause to turn over/around'

The overt derivational marker here looks like the reflexive pronoun (which in German is only distinct from personal pronouns for 3rd person, singular as well as plural: sich). With certain verbs, such as those of postural change (sich setzen, sich legen), the divide between a half-way genuine reflexive, perhaps with attenuated referential force, and a middle marker may be tenuous. But then, middle marking is not only a lexically circumscribed pattern, but figures productively in

“causing-event”, “author”, “agent”, or "self-agentive” causation) in verb roots (Talmy 2000: Chapters 1 and 2). Japanese and Spanish were Talmy's examples of opposite preferences for causation-exclusive and causation-inclusive verb roots, respectively. 
the syntax of voice, and here the distinction is clearcut: for just about all verbs where partial responsibility for the state of affairs designated can be attributed to a non-agent, their lexical subject can be demoted and omitted, with the verb accompanied by a reflexive look-alike, not a real reflexive (e.g., Die Tür öffnete sich lit. 'the door opened itself', Das Buch liest sich leicht lit. 'the book reads itself easily', In diesem Bett schläft sich gut lit. 'in this bed sleeps itself well'). ${ }^{4}$ And passive, too, is available as a syntactic means of detransitivisation in German.

With lexical and also syntactic middles, there are dialectal differences, with Bavarian in its Austrian form probably fondest of such reflexive lookalikes and using them with many verbs where Standard German or other varieties wouldn't (e.g., sich spielen 'to be playing'). ${ }^{5}$ Where this middle marker is optional, as in some of the examples in (2), verbs could equally be categorised as either valency-reducing or ambitransitive, affecting the overall typological verdict. Also, there are sometimes other formal means to distinguish intransitives and transitives even for the same pairs, such as alternations of stem vowels (e.g., sitzen 'sit, be seated' - setzen 'set, seat', futtern 'eat, stuff oneself' (colloquial) - füttern 'feed') which Nichols et al. do not code as being directed, and which would therefore have to be credited to the account of indeterminateness.

Still, on the whole, what Nichols et al. (2004) conclude about German being partly detransitivising and partly indeterminate is amply supported, on these grounds, by most of their own diagnostic verbs and beyond.

Comparing the other modern Indo-European languages in the sample of Nichols et al. (2004), it would appear that lexical valence orientation is diachronically not exactly superstable, at least at the time depth of some 8,000 years. For animate-argument verbs Russian (Slavonic) and Greek (Hellenic) are classified as detransitivising like German (Germanic), ${ }^{6}$ Western Armenian (Armenian being ungrouped within Indo-European) and Hindi (Indo-Aryan) as transitivising, and Portuguese (Romance) and Ossetic (Iranian) as indeterminate. Russian and Greek are also classified as detransitivising and Hindi as transitivising for inanimate-argument verbs, with the rest indeterminate like German. The point of

4 Such valency reduction through reflexive look-alikes has been interpreted as reflexivisation proper by Koontz-Garboden (2009). For a more plausible semantics of middles see, among others, Kaufmann (2007).

5 Slavonic influence is a possibility here.

6 More accurately, Greek is classified as detransitivising/neutral. 
departure in Proto-Indo-European, according to Nichols (1982), had been prevalent detransitivisation. (The diachronic expectation of Nichols (1982: 459) had been that basic intransitivity or transitivity is a conservative trait, able to brave millennia of grammatical transformation.)

However, taking a closer look at form relations in valency pairs, among their own exemplars and beyond, where Nichols et al. fail to see directed derivation or prefer to reserve judgement, a different disposition emerges for German which is at odds with co-existing detransitivisation in terms of middle marking and indeterminateness in terms of verb ambitransitivity. The relevant formal patterns are to do with the morphology of verbal conjugation classes and its associated phonology and with the incidence of umlaut in verb derivation: in these terms, German is solidly transitivising. Our argument for a transitivising interpretation of what might seem symmetric oppositions rests on the distinction of strong and weak verbs, which is a distinction of inflection classes, and further on the incidence of umlaut when deriving weak verbs from adjectives and nouns. Crucially, there are connections between the conjugation class distinction of strong and weak and derivational morphology on the one hand and the syntax and semantics of transitivity on the other. What motivates our analysis of directed derivation are phonological patterns associated with (or rather dissociated from) conjugation class distinctions. The phonological patterns where we will argue for directedness - which unlike the addition of segmental material did not come under the macroscope of Nichols et al. $(2004)^{7}$ - are first ones of ablaut (Section 3 and Section 4), second of umlaut (Section 5).

Upon applying the microscope the very distinction between affixation and phonological alternation itself might become blurred. There are theoretical frameworks where mere featural as well as tonal changes - "phonological alternations" to the naked eye - are analysed as affixation (see Akinlabi 2011 and Hyman \& Leben 2000 for overviews). Also, genuinely segmental affixations may, on the surface, appear as subsegmental phonological modifications (e.g., Bavarian heilig /'harlıg/ 'holy', basic form - heilig- $n$, with plural suffix, surfacing as the feature NASAL added to the stem-final velar, ['harlın]; such non-transparent morphology is surveyed in Plank 1985). For present purposes, however, we continue to conceive of ablaut and umlaut as "phonological" realisations of morphological contrasts in the language at

7 Nor those of Haspelmath (1993), Comrie (2006), or Cysouw (2008, 2010). 
issue, as opposed to the straightforwardly directional morphological and syntactic additions of segmental material.

\section{Strong = basic and intransitive, weak = derived and transitive in German}

\subsection{Valency alternation other than through derivational morphology}

In contemporary German it is common for pairs of valency-alternating concepts to be expressed as follows:

(i) through identical verbs used in both syntactic frames (ambitransitive, also known as labile, (3), although this is not quite as common as in, say, English);

(ii) through different verb stems (i.e., suppletively, (4));

(iii) through contrasting light (or lightish) verbs in construction with nominalisations ("Funktionsverbgefüge" in Germanist terminology, (5));

(iv) through periphrasis with causative verbs such lassen 'let' or (more rarely) machen 'make' (6);

(v) or also through verb prefixes (7).

Our illustrations are subclassified as animate-argument (a) and inanimate-argument (b) à la Nichols et al. (2004): ${ }^{8}$

(3) Identical verbs LOWER-VALENCY HIGHER-VALENCY

a. lernen 'learn'

lernen 'teach'

b. kochen 'be cooking' (as an informal alternative to lehren) an-brennen 'catch fire' kochen 'prepare food by heating' an-brennen 'set on fire' ver-brennen 'be consumed by fire' ver-brennen 'destroy by fire'

8 Although verb prefixes can be implicated in valency alternations of this kind, their alignment is rarely systematic; their primary functions rather are aspectual (as in (3b)), applicative (e.g., wohnen 'reside' - be-wohnen 'inhabit'), and noun-classificatory (e.g., schießen 'shoot game' er-schießen 'shoot people or pets'); see Plank (1984) for a typological appreciation. 
(4) Verb suppletion

LOWER-VALENCY

a. essen 'eat'

sehen 'see'

lernen 'learn'

haben 'have'

b. sein 'exist'

herrschen 'prevail'

(5) Light verb contrasts

LOWER-VALENCY

a. in Gelächter ausbrechen

'burst with laughter'

b. in Brand geraten 'catch fire' zur Aufführung kommen 'be performed'

(6) Causative verb periphrasis

LOWER-VALENCY

a. sehen 'see'

b. auf sein 'be open'

(7) Verb prefixation

LOWER-VALENCY

a. leben 'live' er-starken 'get stronger'

b. enden 'come to an end'
HIGHER-VALENCY

füttern 'feed'

zeigen 'show'

lehren 'teach' (only opaquely related)

geben 'give'

schaffen, machen... 'cause to exist'

verursachen 'bring about'

HIGHER-VALENCY

zum Lachen bringen 'bring to

laugh'

in Brand stecken 'set on fire'

zur Aufführung bringen 'perform'

HIGHER-VALENCY

sehen lassen 'show'

auf machen 'make open'

HIGHER-VALENCY

be-leben 'bring to life'

(ver-)stärken 'strengthen'

be-enden 'bring to an end'

There are indications of asymmetries here insofar as it is valency-augmentation rather than reduction which is expressed through periphrastic constructions or through verb prefixes. In "Funktionsverbgefüge" pairs, however, it is sometimes a lower-valency (e.g., lachen 'laugh') and sometimes a higher-valency concept (e.g., aufführen 'perform') which can be expressed through the simple verb, too. Even with ambitransitive verbs, with no formal indications of derivedness, there are semantic subclasses where either the lower-valency or the higher-valency constructions would seem more basic: for example, Die Bar öffnet um 9 'The bar opens at 9' is arguably a non-basic intransitive construction because of semantic restrictions on the intransitive subject (with middle-marked sich öffnen semantically unrestricted, and with öffnen basically transitive); by contrast, Sie segelte das Boot nach Lindau 'She sailed the boat to Lindau' is arguably a non-basic transitive construction (with segeln basically intransitive, itself derived from the noun Segel). 
Even if detransitivisation and indeterminateness between them are not wholly pervasive, there are more systematic asymmetries elsewhere that run counter to the generalisation of Nichols et al. (2004).

\subsection{Valency alternation through derivational morphology?}

On the face of it, morphologically tangible verb-to-verb derivation for purposes of either valency-augmentation or valency-reduction would not seem prominent in contemporary German. But then, a survey of contemporary cases of causative verbs bearing some phonological similarity to non-causative counterparts, with the phonological and semantic connection sometimes transparent and sometimes more idiosyncratic and tenuous, brings to light a consistent asymmetry: all such causative verbs belong to the weak conjugation, while their non-causative counterparts are all strong. ${ }^{9}$ Here is a list of such verb pairs (culled from a dependable handbook, Fleischer et al. 1992: 349), so far as possible subdivided into animate- and inanimate-argument verbs à la Nichols et al. (2004); all are rather central members of German vocabulary, mostly to do with sustenance and posture and motion:

(8)

NON-CAUSATIVE
a. essen 'eat'
trinken 'drink'
er-saufen 'drown' (be killed)
ge-nesen 'convalesce'
saugen 'suck'
beissen 'bite'
sitzen 'sit'
liegen 'lie'
hängen 'hang'
fahren 'drive, ride'
springen 'spring, jump'
dringen 'penetrate'

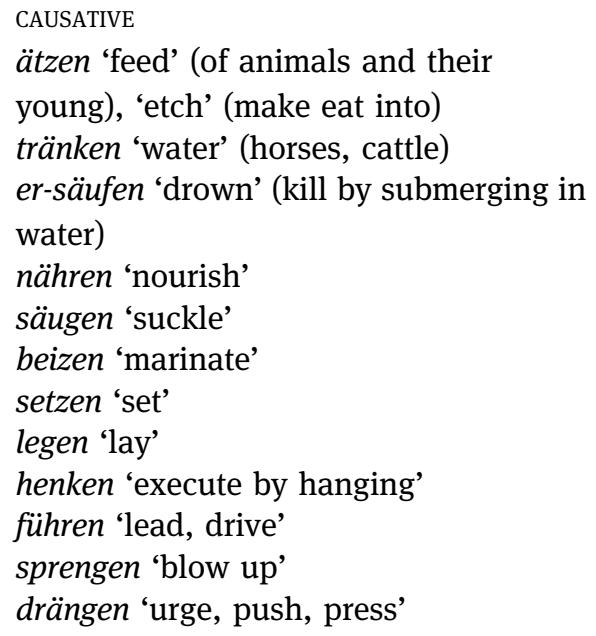

9 This is not entirely accurate for two verbs in (8a): saugen and hängen vacillate between strong and weak, as will be explained subsequently. 
b. fallen 'fall'

schwimmen 'float, swim'

fließen 'flow'

sinken 'sink'

rinnen 'run, trickle'

(sich) winden 'wind'

(sich) biegen 'bend, bow'

schwingen 'swing'

(ver-)schwinden 'disappear, decrease' fällen 'fell'

schwemmen "carry along in a given

direction' (in and by flowing water)

flößen 'cause to float'

senken 'cause to sink, lower'

rennen 'run, race' ${ }^{\text {,0 }}$

wenden 'turn'

beugen 'make bend, bow'

schwenken 'cause to move in a to-and-

fro motion'

ver-schwenden 'squander'

For a derivational pattern that may seem residual - and there is no question of synchronically productive derivation here - this conjugational alignment is remarkably systematic. The weak conjugation has often been referred to as REGULAR and the strong conjugation as IRREGULAR. Given that morphologically derived words will join unmarked or default inflection classes, this conspicuous asymmetry could be made sense of by assuming that the valency-augmented, causative verbs are derived and their lower-valency counterparts are basic except there is no segmental-additive, synchronically regular derivational morphology that would be doing the deriving.

\subsection{Weak and strong conjugations and in between}

This reasoning is too rash, however: there may be a sense in which the weak and strong conjugations in German can be considered "regular" and "irregular" respectively, hence to be the natural homes for derived and basic verbs respectively; but this distinction of verbal inflection classes is more complex than its counterpart in morphologically impoverished Germanic languages such as English.

The inflectional contrast between weak and strong verbs in German consists in a whole series of individual differences, rather than only in past tense and resultative participial formation as in Modern English. These individual differences relate to stem vowel as well as suffix choices, and it is not self-evident which choices could be said to be regular and irregular:

10 Causative only in the sense of self acting upon self to keep running, which sense is absent from the inanimate-argument intransitive counterpart. This has also been considered a special aktionsart rather than as causative (e.g., Van Valin 2006). 
(9)
a. PAST tense

b. PARTICIPLE II

c. 2/3SG.IND.PRES

d. 2sG.IMP

e. PAST SUBJUNCTIVE
WEAK

formed concatenatively with dental suffix right after stem and before inflectional ending: e.g., leb-t- live-PAST-

stem vowel unchanged: ge-leb-t PRTCP-live-PRTCP

stem vowel unchanged:

leb-e, leb-st, leb-t live-1sG/2sG/3sG

ditto:

leb-e live-2sG.IMP no umlauting f. nominalisation

sag-t-e say-PAST-1/3sG.IND,
^ü̈g-t-e
say-PAST.SUB-1/3sG.suB
no stem-vowel change,
zero suffix uncommon

STRONG

ablaut alternations:

e.g., starb- die.PAST-, vis-à-vis sterb- in present

ablaut alternations: ge-storb-en PRTCP-diePRTCP $e / i$ alternation or umlaut with appropriate stem vowels: sterb-e, stirb-st, stirb-t die-1sG/2sG/3sG ditto: stirb- $\emptyset$ die-2sG.IMP stems with a back vowel umlaut it (and this vowel is not necessarily the umlaut counterpart of that of the past indicative): starb- $\varnothing$ die.PAST-1/3sG. IND, stürb-e die.PAST.SUB-1/3sG.suB ablaut alternation especially with zero suffix: reiten, ritt, geritten - Ritt 'ride, rode, ridden - a ride'

11 There are only a couple of weak verbs which also change the stem vowel in zero nominalisations: ersetzen - Ersatz 'replace' - 'replacement', verlegen - Verlag 'publish' - 'publishing/ publisher'. Although the nominalisations are from transitive weak verbs, these weak verbs themselves have corresponding intransitive strong verbs: sitzen, saß, gesessen 'sit, sat, sat'; liegen, lag, gelegen 'lie, lay, lain'. 
g. PARTICIPLE II

h. $1 / 3$ SG.IND.PAST

i. 2SG, 3SG.PRES.IND

j. 2SG.IMP

dental suffix -(e)t,
prefix ge-, only
materialising
before a stressed syllable:
ge-LEB-t; [ge-]er-LEB-t,
unstressed inseparable
prefix er-
suffix - - :
leb-t-e live-PAST-1/3sG.IND.
PAST
suffixes -est, -et (with
schwa)
with stem-final /t/:

schalt-est, schalt-et 'switch'

suffix - $e$ (but possibly omitted in informal speech):

leb-e brechen, brach, gebrochen - Bruch 'break, broke, broken a breach'

(with further alternation $o / u)$ suffix -en, prefix ge-, as with weak verbs:

ge-storb-en; [ge-]verSTORb-en, unstressed inseparable prefix ver-

$-\varnothing$ :

starb-Ø die.PAST-1/3sG. IND.PAST

-st, - $t$ (without schwa)

with stem-final / $\mathrm{t} /$ and

$e / i$ alternation or umlaut: ${ }^{12}$

hält-( $\left.{ }^{*} e\right) s t$, hält- $\left({ }^{*} e\right) t$

'hold'

(with final /tt/

degeminated, also orthographically) $-\emptyset$ (especially if there is a stem-vowel alternation): stirb-Ø, reit(-e)

Verbs are fully weak and fully strong if they differ on all ten or so counts, as most of them do. However, this inflectional class distinction is not always categorical, insofar as some verbs mix weak and strong properties, which after all are all logically independent of one other. For example, werd- 'become' is (always) strong in some respects, but (always) weak in others:

12 Strong verbs in final /t/ whose stem vowel cannot undergo umlaut or the $e / i$ alternation likewise insert schwa before $2 \mathrm{sg}$-st and 3sG -t: e.g., reit-est, reit-et 'ride'. 
(10)
a. PAST tense
b. PARTICIPLE II
c. 2/3SG.IND.PRES
WEAK
${ }^{\star}$ werd-et-
*ge-werd-et
werd-e, ${ }^{*}$ werd-est, ${ }^{*}$ werd-et

d. 2SG.IMP

e. PAST SUBJUnCtive

g. PARTICIPLE II

h. 1/3SG.IND.PAST

j. 2SG.IMP werd-e

${ }^{\star}$ werd-e

*ge-werd-et

wurd-e

werd-e
STRONG

wurd-

ge-word-en

werd-e, wir-st, wird

(with some formal

irregularities of

this high-frequency

verb)

${ }^{\star}$ wird-e

würd-e

ge-word-en

${ }^{\star}$ wurd- $\varnothing$

${ }^{\star}$ wird-Ø

Or, less thoroughly mixed, spalten 'split', mahlen 'grind', or winken 'wave' inflect weakly except for their participles, which are strong: ge-spalt-en, ge-mahl-en, gewunk-en (though with weak ge-spalt-et, ge-mahl-t, ge-wink-t also possibilities). The choice of weak or strong forms in such mixed repertoires is not random, but follows an orderly continuum, with resultative participle (also referred to as participle II) and past subjunctive as the likeliest forms to be (or remain) strong and with 2sG imperative and 2/3sG indicative present as the likeliest forms to be (or become) weak (Bittner 1996, Bittner \& Köpcke 2007).

Further, there are two handfuls of verbs which do not mIx strong and weak properties in the manner of werden or spalten, mahlen, winken, but rather VACILLATE between inflecting consistently strongly when intransitive or consistently or predominantly weakly when transitive - here again divided up into animate- and inanimate-argument verbs:

(11) a. erschrecken 'be frightened' - 'frighten' (with English counterparts such as frighten, startle, scare transitive)

b. hängen 'be supported from above' - 'support from above' (with the English cognate, hang, intransitive and transitive too, with an analogous inflectional distinction: intransitive hang, hung, hung - transitive hang, hanged, hanged, though only in the specialised sense of executing by hanging);

stecken 'be in a fixed position, unable to move' - 'fix something pointed in a position' (with the English cognate, stick, intransitive and transitive too, but consistently strong);

quellen 'gush forth, grow bigger' - 'cause to grow bigger' (with the English counterpart, swell, intransitive and transitive too, and with 
the resultative participle alternating between strong and weak too: intransitive swollen - transitive swelled);

schmelzen 'become liquefied by heat' - 'cause a change to a liquefied condition by heat, extract metal from ore by melting' (with the English cognates melt and smelt, the former intransitive and transitive too, but with a strong form only surviving in adjectival molten; the latter only transitive and weak);

schleifen 'trail along' - 'pull along with effort' (with the English counterpart, drag, intransitive and transitive too, but consistently weak); wiegen 'have a specified weight' - 'determine the weight of something' (with the English cognate, weigh, intransitive and transitive too, but consistently weak);

backen 'undergo the process of baking' - 'cause food to undergo the process of baking' (with the English cognate, bake, intransitive and transitive too, but consistently weak); ${ }^{13}$

bleichen 'turn pale or white, fade' (with prefixes er- or ver-) - 'cause to become whiter through exposure to sunlight or chemical means' (with the English cognate, bleach, intransitive and transitive too, but consistently weak);

löschen 'go out, die down' (typically applied to fire, with prefixes er- or ver-) - 'put out, extinguish, erase, cancel' (also with prefixes other than er-)

The conventional story here is that in the course of time strong (irregular) verbs have tended to become weak (regular), and such vacillation as with these ten or so verbs, just as in the case of mixed strong-weak verbs, is a transitional stage in the change of conjugation class. Arguably, however, class changes from strong to mixed (stable or more commonly unstable) and eventually to fully weak are a different kind of phenomenon from stable vacillation between strong and weak. It is precisely in such instances of vacillation that the alignment pattern strong $=$ intransitive and weak = transitive is pertinaciously continuing to manifest itself, as will be shown below (Section 4).

13 In contemporary German, backen 'bake' is probably mixed rather than vacillating: its participial form would invariably seem to be ge-back-en (strong), with the strong past bukarchaic vis-à-vis more common weak back-t- and with indicative forms undecided between umlaut (bäck-st, bäck-t) or no umlaut (back-st, back-t). 


\subsection{Diachrony of weakness}

Taking a diachronic perspective, the inflection class distinction between strong and weak verbs is seen to have developed from a distinction between basic and derived verbs. ${ }^{14}$ Weak verbs in Common Germanic were verbs derived from verbs, adjectives, nouns, and also a few adverbs and ideophones/expressives, by means of suffixes, viz. -j ([i] before consonant), $-\bar{o},-\bar{e}$. A fourth weak class were verbs in -nă/-nō, but these appear to have been limited to East and North Germanic, with only a few instances (relics or borrowings) attested in West Germanic. These derivational suffixes were inherited from Indo-European, but became increasingly productive, with the first weak subclass ( $-j$, with infinitival ending -jan) as the most successful followed by the second ( $-\bar{o}$, with infinitival ending $-\bar{o} n$ ). They came to cover a range of semantic functions to do with valency alternation on the one hand and aspect and aktionsart on the other. The valency-related functions included causative (also called factitive when the base is an adjective), inchoative (or also essive or durative: 'to be ADJ', rather than 'to become ADJ'), decausative (the fourth class, -nă/-nō, never productive in West Germanic), and what has sometimes been called "contextual" ('to do what is characteristically done with NOUN or what NOUN characteristically does'); the chief aspect or aktionsart functions were iterative and intensive. On the formal side, in West Germanic the addition of the derivational suffix $-j$ was to cause umlaut (i.e., fronting of stem vowels) when no consonant cluster prevented it and to trigger gemination of final consonants when verb stems were light (i.e., had a short vowel). Importantly for present purposes, these regular phonological effects upon basic stems were to survive, in one form or another or also analogically interfered with, even after the suffix $-j$ itself fell victim to regular sound change. ${ }^{15}$ (See, for example, the Modern German verb pairs in (8) above.)

Over time, links between individual bases and derivatives were loosened or severed owing to the members of such pairs undergoing separate phonological

14 And inflection classes in general commonly have such origins in derivation. For Germanic, the basics of the origins and development of weak verbs are to be found in any handbook. The weak verbs specifically of Old High German are collected in Raven (1963/1967). Two recent, extensively documented and referenced comparative studies with a focus on the derivational functions of weak verbs are Riecke (1996) and Schwerdt (2008).

15 As did $-\bar{o}(>o>\partial)$, though without such regular stem effects. Sometimes such Weak Class 1 effects were analogically extended, though: e.g., umlaut with öffn-en 'to open', originally an -ōn verb, Old High German offan-ōn, Weak Class 2. See Section 5 below. 
and semantic developments, or erstwhile bases were lost altogether. ${ }^{16}$ Still, for contemporary German (and its Germanic relatives), where the weak conjugation has essentially become one single inflection class, it continues to hold that, while not all weak verbs are recognisably derived, if a verb is derived it will perforce inflect weakly. ${ }^{17}$

Given that the higher-valency members of such pairs as in (8) and (11) (that is, in transitive uses in the case of (11)), all inflecting weakly, can be related to lower-valency verbs that all inflect strongly, it is in line with the asymmetry that continues to define the spirit of the morphological system to consider highervalency as derived from lower-valency rather than the other way round - even if this is derivedness rather than productive, online derivation.

\subsection{Representation of strong and weak}

Since strong vs. weak subsumes a whole range of elementary distinctions (ten, as shown in (9)), how this conjugation class difference is represented in the mental lexicon-and-grammar of speakers of German is not a trivial question.

Historically, much of this complexity is due to the phonology of verb inflection. The suffix -j of derived ("weak") verbs umlauted stem vowels and geminated stem-final consonants; as a result such verbs failed to fit into the templatic patterns of ablaut-alternating vowels which basic ("strong") verbs in Common Germanic employed for forming tenses (or earlier aspects). Periphrasis with 'do' was resorted to to create a new past tense for such verbs; and such syntactic constructions with a derived verb stem (or possibly a nominalised or adjectivalised form) plus following light verb 'do' were morphologised, eventually yielding the dental suffix for the weak past tense shared by all Germanic languages (thus: 'he paint-PAST' < 'he paint-j did' or 'he paint-j-PARTICIPLE made'). The differing suffixes of the resultative participle derive from different IndoEuropean suffixes for verbal adjectives, -no (strong) and -tó (weak). The stem

16 Already in Old High German almost half of the attested weak verbs of Class 1 (-jan) appear to have had no obvious base (Schwerdt 2008: 130; details in Riecke 1996: 370-394, 499-518, 550559, 567-581, 601-611, 616-621, 624-633, 635-638. 646-650, 653-660, 662, 664). Assumptions of "primary", genuinely underived weak verbs (such as Germanic *sōk-j-an 'seek', German suchen) are therefore suspicious.

17 Very exceptionally, salzen 'to salt' prefers a strong (ge-salz-en) over a weak (ge-salz-t) resultative participle, even though the verb is synchronically clearly denominal (Salz 'salt'); however, diachronically the direction of derivation was an intricate story. Also, gleichen 'be like' has turned strong (see Section 4.3 below), even though it would seem to continue to be based on the adjective gleich 'equal'. 
vowel alternations or non-alternations were a matter of ablaut on the one hand and umlaut or $e / i$ alternation on the other, triggered by derivational $(-j)$ and inflectional suffixes of verbs in their early Germanic forms (often containing /i/, frequently a victim of final high vowel deletion). ${ }^{18}$

But isn't this is all remote history? No, because to some extent it translates into mental lexicons-and-grammars of contemporary speakers. In particular, the way strong and weak verbs are represented and processed in a modern Germanic language like German, the relationship continues to be a directed one when two of them are derivationally related, despite the lack now of an overt suffix like Common Germanic - $j$ that would give away the direction even when no microscope is handy. On our analysis, the relevant derivational operation consists in the dissociation of phonological feature fill-in from inflectional categories. The direction of derivation must be from strong to weak, because from the unspecified stem vowel of a weak verb the lexical stem vowel specification and the stem vowel alternations of a corresponding strong verb would be unpredictable, whereas the other way around the phonology and morphology are predictable: there are several subclasses of strong verbs differing in ablaut alternations, but there is only one (by now) homogeneous weak inflection.

This is a complex argument, and here we can only recapitulate the longer story as told in several instalments elsewhere. Our argument rests on lexical entries which are abstract insofar as their phonological representations are not fully specified. The version of underspecification that we subscribe to is the model of a Featurally Underspecified Lexicon (FUL, as developed in Lahiri \& Evers 1991; Ghini 2001; Lahiri \& Reetz 2002, 2010; etc.). In what follows we will sketch (i) how the stem vowels of strong verbs are lexically underspecified and (ii) how featural specifications are filled in, either following general phonological principles to do with redundancy or - and this is what distinguishes strong verbs from weak verbs - determined by inflectional categories.

A major challenge of German(ic) verb inflection for (phono-)morphological theory is to account for the ablaut patterns without resorting to mere stipulation of the full series of vowel alternations for each strong verb. It is part of this challenge also to limit the $e / i$ and umlaut alternations in the present tense and imperative to just the strong verbs ((9c) above: sterb-en, stirb-st, stirb-t, stirb- $\varnothing$; but leb-en, leb-st, leb-t, leb-e). These are crucial alternations that need to be

18 See Lahiri (2000) for our take on the the origin and development of the dental preterite, and Lahiri (1982) on / $\mathrm{j} /$-effects in Germanic verb inflection. Although this is a notoriously controversial subject, a "supporting" verb 'do' is by far the most plausible source of the dental preterite suffix, and derivation-triggered phonology is the only plausible reason for the need of such periphrastic past tense marking in the first place. 
accounted for, exemplified from such strong verbs as have weak counterparts ((11) above):

(12)

\begin{tabular}{llllllll} 
INFINITIVE & \multicolumn{3}{c}{ 2SG.IND.PRES } & & 1/3SG.IND.PAST & & PARTICIPLE II \\
erschrecken & {$[\varepsilon]$} & erschrickst & {$[\mathrm{I}]$} & erschrak & {$[\mathrm{a}]$} & erschrocken & {$[\mathrm{J}]$} \\
hängen & {$[\varepsilon]$} & hängst & {$[\varepsilon]$} & hing & {$[\mathrm{I}]$} & gehangen & {$[\mathrm{a}]$} \\
stecken & {$[\varepsilon]$} & steckst & {$[\varepsilon]$} & stak & {$[\mathrm{a}]$} & (gesteckt) & {$[\varepsilon]$} \\
bleichen & {$[\mathrm{aI}]$} & bleichst & {$[\mathrm{aI}]$} & blich & {$[\mathrm{I}]$} & geblichen & {$[\mathrm{I}]$}
\end{tabular}

It is the past tense that gives the best rate of predictability for alternating stem vowels across the ablaut classes (Halle 1953, Scharinger 2002, Scharinger et al. 2009); but the resultative participle too needs to be referred to along with the past tense as a predictor, hence the traditional three "Kennformen" or principal parts of German strong verbs (INF erschrecken, PAST erschrak, PARTICIPLE II erschrocken). ${ }^{19}$

The phonological surface features of the crucial vowels that we are considering, as extracted from the speech signal by the human ear, are as in Table 1. The shaded column indicates that CORONAL is always underspecified in lexical representations. Since features are privative, mid vowels are not specified for height; they are neither high nor low.

Table 1: Surface Tongue Height and Articulator features of German vowels. ${ }^{a}$

\begin{tabular}{|c|c|c|c|c|c|}
\hline & \multicolumn{2}{|c|}{ TONGUE HEIGHT } & \multicolumn{3}{|c|}{ ARTICULATOR } \\
\hline & HIGH & LOW & CORONAL & DORSAL & LABIAL \\
\hline I & $\sqrt{ }$ & & V & & \\
\hline$v$ & $\sqrt{ }$ & & & V & V \\
\hline$\varepsilon$ & & & V & & \\
\hline$a$ & & $\sqrt{ }$ & & V & \\
\hline כ & & & & V & V \\
\hline
\end{tabular}

${ }^{a}$ For the full picture of feature organisation in FUL see Lahiri \& Reetz (2010).

The shaded column for CORONAL indicates that the feature is available on the surface but underspecified in lexical representations.

19 It is frequently the past tense form which serves as the base for derivation - as with many of the non-causative bases in (8) above: trinken 'drink' - Trank 'a drink', beissen 'bite' - Biss 'bite', saugen 'suck' - Sog 'suction', fahren 'drive, ride' - Fuhr-e 'a haul, load', etc. The vowel of the resultative participle, too, may surface in such nominalisations: springen 'spring, jump' Sprung ‘a jump, crack'. 
Now, "strong" verbs are verbs whose stem vowel specifications are dependent on categories of verb inflection; deriving a "weak" verb from a strong verb means, not to add a suffix, as used to be the case in older Germanic, but to ELIMINATE THESE DEPENDENCIES and DELINK THE FILLING IN OF VOWEL SPECIFICATIONS FROM INFLECTIONAL CATEGORIES. The stem vowels of weak verbs $-/ \varepsilon /$ and $/ a$ : / for the verbs exemplified in (11) when they are transitive - may also be lexically underspecified; but specifying them is a matter of phonology, to do with redundancies in feature systems, rather than of morphology.

This underspecification account has a production and a perception side, as sketched in Tables 2 and 3 for representative verbs of the vacillating type. The filling in of features happens in production, as dictated by phonological redundancy rules and linked with (strong verbs) or independent of (weak verbs) inflectional categories (Tables $2 \mathrm{a} / \mathrm{b}$ ). From a perception point of view, the crucial considerations are these: (i) the hearer extracts features from the signal which can MATCH or NOT мISMAтсH or мISMAтсH with the lexical representation (for example, HIGH and LOW would mismatch; CORONAL mismatches DORSAL, but not the other way around, because CORONAL is not lexically specified); (ii) verb stems are represented in such a way that none of the surface forms мISмAтcH with the stem; (iii) if a representation is underspecified, then whatever is extracted from the signal is tolerated by the representation (о мізматсн). For example, in Table 3a, in the lexical representation of the strong verb erschrecken the stem vowel (assumed to be [a:]) has the ARTICULATOR feature LABIAL, and no TONGUE HEIGHT feature is represented. The vowel [0] of its participial form has two ARTICULATOR features, LABIAL and DORSAL, and no TONGUE HEIGHT features on the surface. The surface feature LABIAL matches with the one in the lexical representation, but since DORSAL is not lexically represented, there is a no mismatch. Similarly, since [0] has no HEIGHT feature extracted, again it does not match or mismatch with the lexical representation.

It is something along these lines that you see when you look through the microscope of in-depth morphological and phonological analysis at the categories conveniently labelled "strong” and “weak" verbs. Now, FUL's assumptions about the mental representations of such verb classes have been tested experimentally. The experiments were designed to determine whether the various inflectional forms of strong, weak, and mixed or vacillating verbs are equally morphologically, and not merely semantically, related to one another regardless of the stem vowel alternations. Another objective was to examine whether the mixed or vacillating verbs, which we predict to have different phonological representations, would show that weak verbs can be derived from strong verbs but not vice versa. ${ }^{20}$

20 For different lines of experimental research we have used to probe derivational complexity see Meinzer et al. (2009). 
Table 2a: Production.

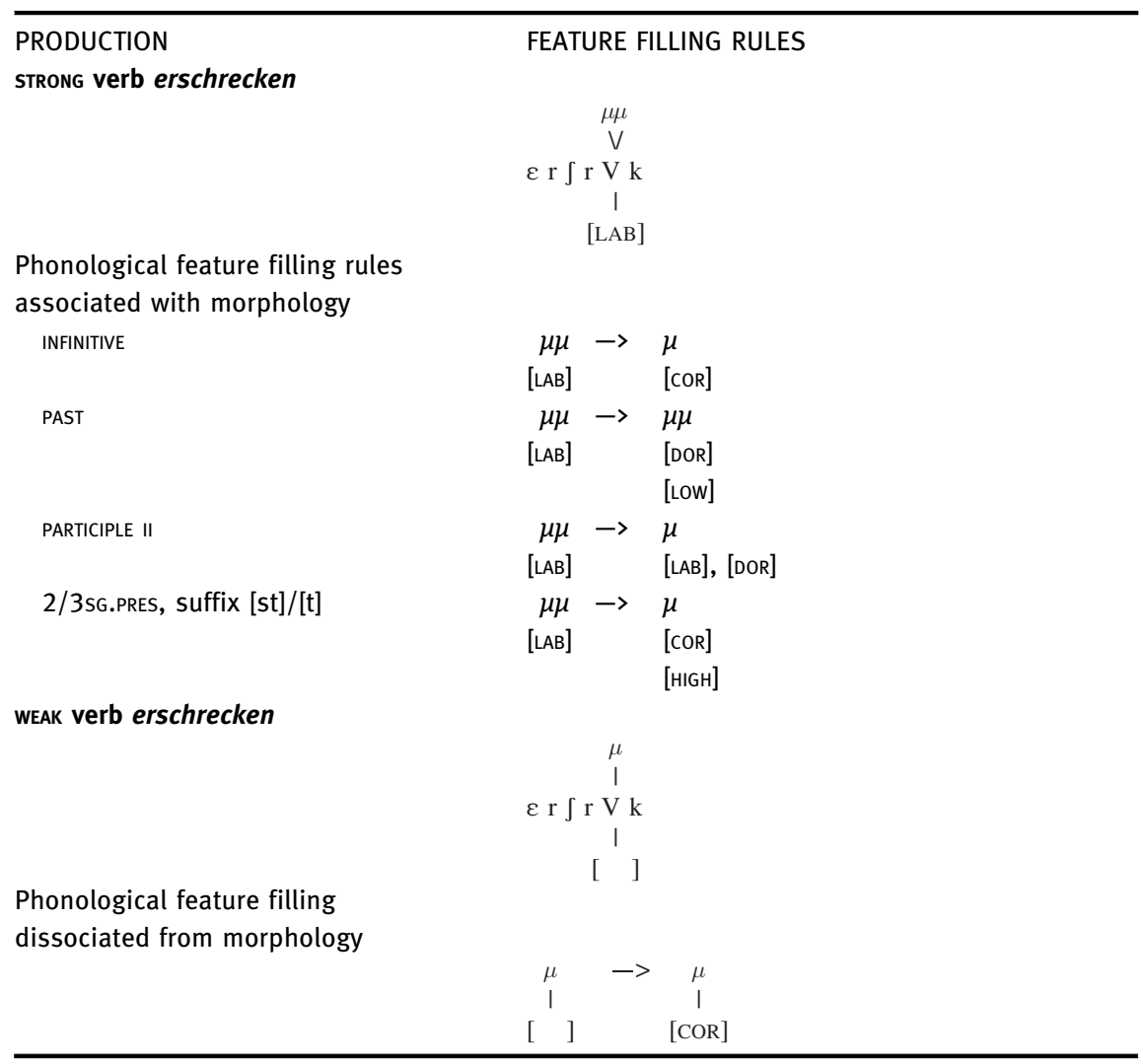

Vowel length is given in terms of moras ( $\mu \mu=$ long).

We ran several priming experiments using an auditory lexical decision task with delayed priming, which is known to distinguish between morphological and semantic relatedness (Scharinger et al. 2009). ${ }^{21}$ As in any priming task, listeners were presented with a TARGET (e.g., backen) preceded by related (e.g., bäckst or brätst) and unrelated (fährst) PRIMES (as shown in Table 4). Both prime and target words were spoken. The difference in reaction time to the target, when preceded by a related prime as compared to an unrelated prime, is the "priming effect".

21 Of the several experiments reported in that study, only one is relevant for present purposes. 
Table 2b: Production.

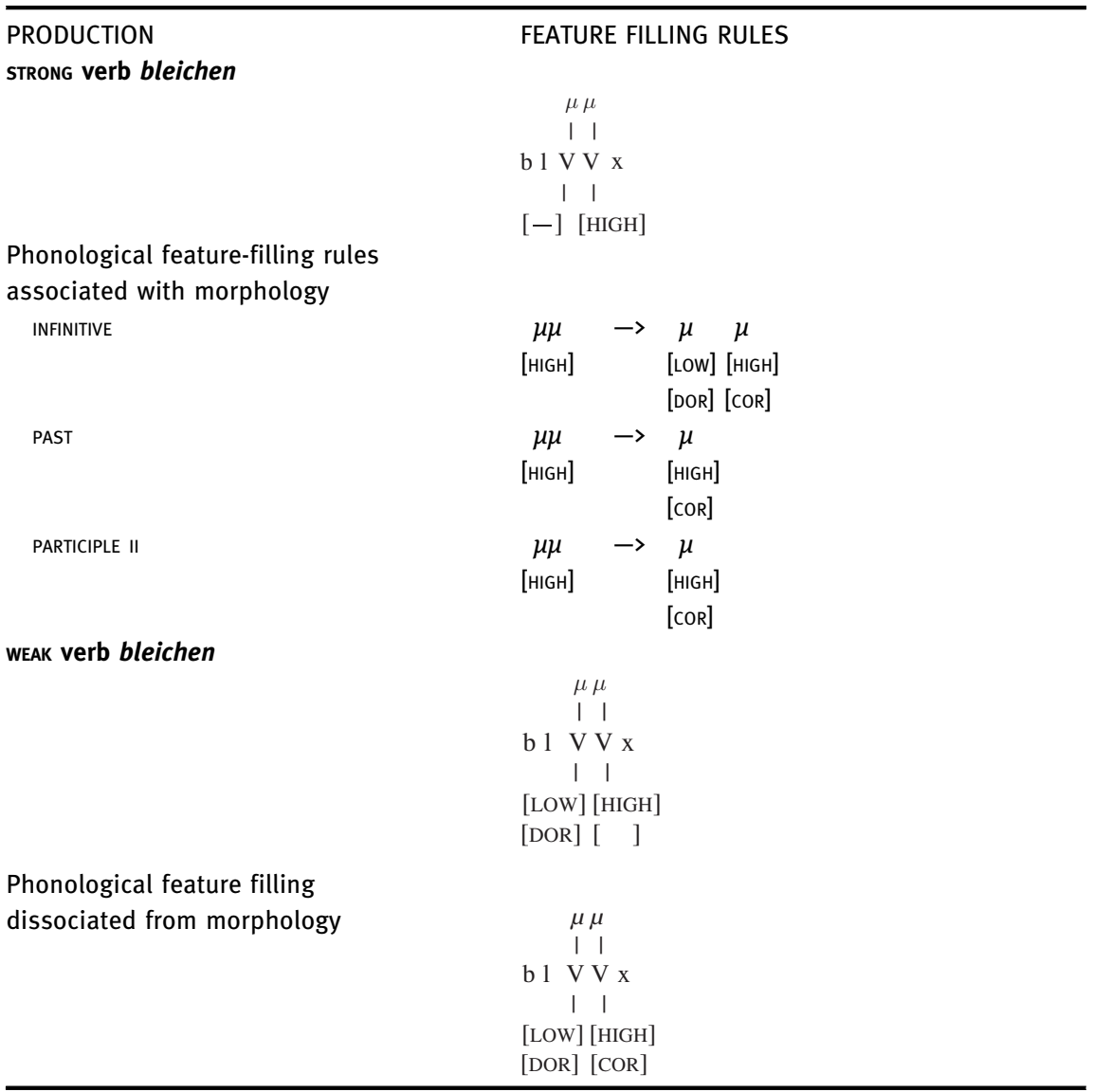

We used a delayed priming task, where listeners hear several words in a list, half of which are words and half are nonwords. The participants' task was to decide whether the words they heard were real words of German. Hidden among the lists were morphologically related as well as semantically related words, to ensure that we obtained morphological rather than semantic priming.

The assumption was that the reaction time to backen would be fastest, compared to the control fährst, if bäckst had already activated the stem. Thus, we would obtain priming, indicating that bäckst and backen are related. Furthermore, if reaction times for the prime brätst were not different from the control fährst, then we could conclude that semantic relatedness did not play a 
Table 3a: Perception (TH $=$ TONGUE HEIGHT; ART = ARTICULATOR).

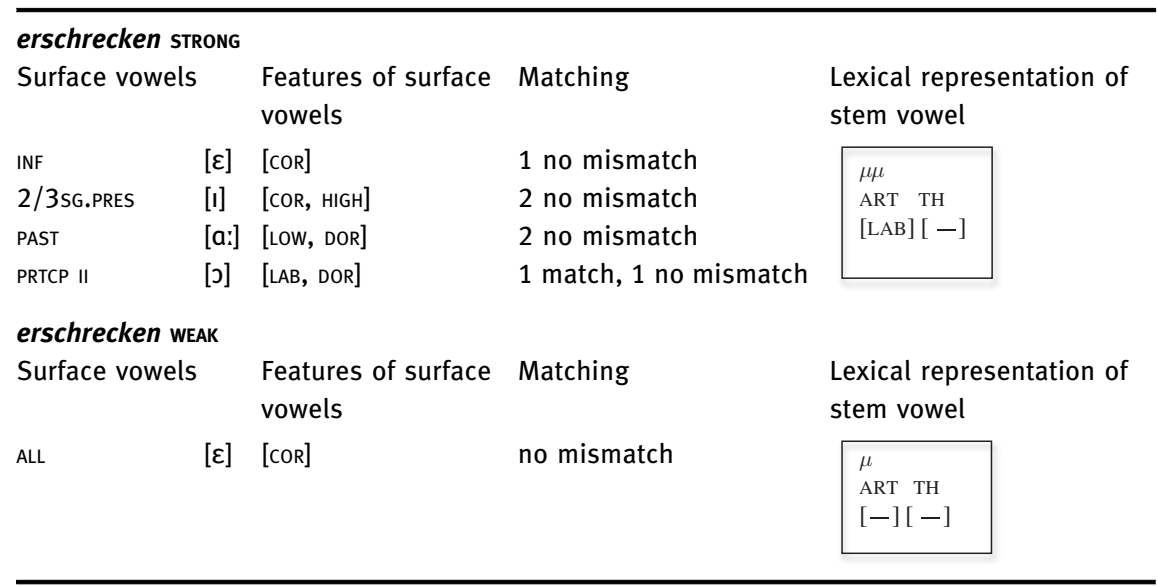

Table 3b: Perception.

\section{bleichen STRONG}

\begin{tabular}{|c|c|c|}
\hline $\begin{array}{l}\text { Surface } \\
\text { vowels }\end{array}$ & $\begin{array}{l}\text { Features of surface } \\
\text { vowels }\end{array}$ & Matching \\
\hline INF [aI] & [DOR] [COR] & 2 no mismatch \\
\hline PRTCP ॥ [1] & $\begin{array}{l}\text { [LOW] [HIGH] } \\
\text { [COR, HIGH] }\end{array}$ & $\begin{array}{l}1 \text { no mismatch, } 1 \text { match } \\
1 \text { no mismatch, } 1 \text { match }\end{array}$ \\
\hline
\end{tabular}

Lexical representation of stem vowel

\begin{tabular}{|ll|}
\hline \multicolumn{1}{|c|}{$\mu$} & \multicolumn{1}{c|}{$\mu$} \\
ART TH & ART TH \\
{$[-][-]$} & {$[-][\mathrm{HIGH}]$} \\
\hline
\end{tabular}

\section{bleichen WEAK}

\begin{tabular}{|c|c|c|c|}
\hline $\begin{array}{l}\text { Surface } \\
\text { vowels }\end{array}$ & $\begin{array}{l}\text { Features of surface } \\
\text { vowels }\end{array}$ & Matching & $\begin{array}{l}\text { Lexical representation of } \\
\text { vowel }\end{array}$ \\
\hline ALL $\quad[\mathrm{al}]$ & $\begin{array}{l}\text { [DOR] [COR] } \\
\text { [LOW] [HIGH] }\end{array}$ & $\begin{array}{l}1 \text { no mismatch, } 1 \text { match } \\
2 \text { match }\end{array}$ & \begin{tabular}{|ccc}
\multicolumn{1}{c}{$\mu$} & \multicolumn{1}{c}{$\mu$} \\
ART & TH & ART TH \\
[DOR] & {$[\mathrm{LOW}]$} & {$[-][\mathrm{HIGH}]$}
\end{tabular} \\
\hline
\end{tabular}

role in this design, and it would only be because they are morphologically related that bäckst primes backen.

Table 5 provides examples of the three types of verbs that were used in our experiments. Although four inflectional forms are listed (INFINITIVE, 2SG.IND.PRES, 2SG.PAST, PARTICIPLE II), the experiments only included INFINITIVE and 2SG.IND.PRES. 
Table 4: Experimental design (delayed priming).

\begin{tabular}{llllll}
\hline Relatedness & Prime & & & Target \\
& 2sG.IND.PREs & & & INF \\
\hline Morphological & bäckst & filler verb & filler verb & filler verb & backen \\
Semantic & brätst & filler verb & filler verb & filler verb & backen \\
Control & fährst & filler verb & filler verb & filler verb & backen \\
\hline
\end{tabular}

Table 5: Examples of strong, weak, and mixed and vacillating verbs in German.

\begin{tabular}{|c|c|c|c|c|c|}
\hline Class & INFINITIVE -en & & 2SG.IND.PRESENT -st & 2sG.PAST -st & $\begin{array}{l}\text { PARTICIPLE ॥ } \\
g e-\ldots-t /-e n\end{array}$ \\
\hline Strong & $\begin{array}{l}\text { schl[a:]fen } \\
\text { s[e:]hen }\end{array}$ & $\begin{array}{l}\text { ‘sleep’ } \\
\text { ‘see’' }\end{array}$ & $\begin{array}{l}\text { schl[E:]fst } \\
\text { s[i:]hst }\end{array}$ & $\begin{array}{l}\text { schl[ii]fst } \\
\text { s[a:]hst }\end{array}$ & $\begin{array}{l}\text { geschl[a:]fen } \\
\text { ges[e:]hen }\end{array}$ \\
\hline Weak & $\begin{array}{l}\text { m[a]chen } \\
\text { l[e:]ben }\end{array}$ & $\begin{array}{l}\text { 'make’ } \\
\text { 'live’' }\end{array}$ & $\begin{array}{l}m[a] c h s t \\
l\left[e^{\prime}\right] b s t\end{array}$ & $\begin{array}{l}m[a] c h t e s t \\
\text { l[e:]btest }\end{array}$ & $\begin{array}{l}\text { gem[a]cht } \\
\text { gel[e:]bt }\end{array}$ \\
\hline Mixed \& vacillating & $\begin{array}{l}\text { b[a]cken } \\
q u[\varepsilon] l l e n\end{array}$ & $\begin{array}{l}\text { 'bake' } \\
\text { 'gush, } \\
\text { soak' }\end{array}$ & $\begin{array}{l}b[a] c k s t \\
b[\varepsilon] c k s t \\
q u[\varepsilon] l l s t \\
q u[I] l l s t\end{array}$ & $\begin{array}{l}b[a] c k t e s t \\
b[u] k \\
q u[\varepsilon] l l t e s t \\
q u[J] l l s t\end{array}$ & $\begin{array}{l}\text { geb[a]ckt } \\
\text { geb[a]cken } \\
\text { gequ[E]llt } \\
\text { gequ[J]llen }\end{array}$ \\
\hline
\end{tabular}

(The third and fourth column in Table 5 are intended to indicate the ablaut alternation in strong and mixed/vacillating verbs.) For each type we chose verbs with infinitives in $/ a /$ and $/ \varepsilon /$ because here the vowel change is seen in the 2sG of strong verbs. ${ }^{22}$ The stem vowel of the $2 \mathrm{sg}$ of the strong verbs is higher than in the corresponding INFINITIVE, viz., $/ \varepsilon /$ and $/ \mathrm{I} /$, while the vowels in the weak verb forms remain unchanged. For the mixed/vacillating verbs $2 \mathrm{sg}$ is variable, being either raised as with strong verbs or remaining unaltered in the weak manner.

Despite the vowel alternations between 2SG and INFINITIVE of the strong verbs, we assumed that they share the underspecified verb stem and therefore would prime each other. However, the crucial conditions were the mixed/vacillating verbs. In Table 6, we provide precise details of our assumptions concerning the underlying representations and surface forms for each of the stem vowels and set out our experimental conditions as well as priming expectations.

As shown in Table 6, although we expect the 2sG forms of the strong verbs schlafen and sehen to activate their underspecified verb stems and prime the

22 Vowel quantity differences, here represented by moras as in the tables below, are not relevant for featural specification. 


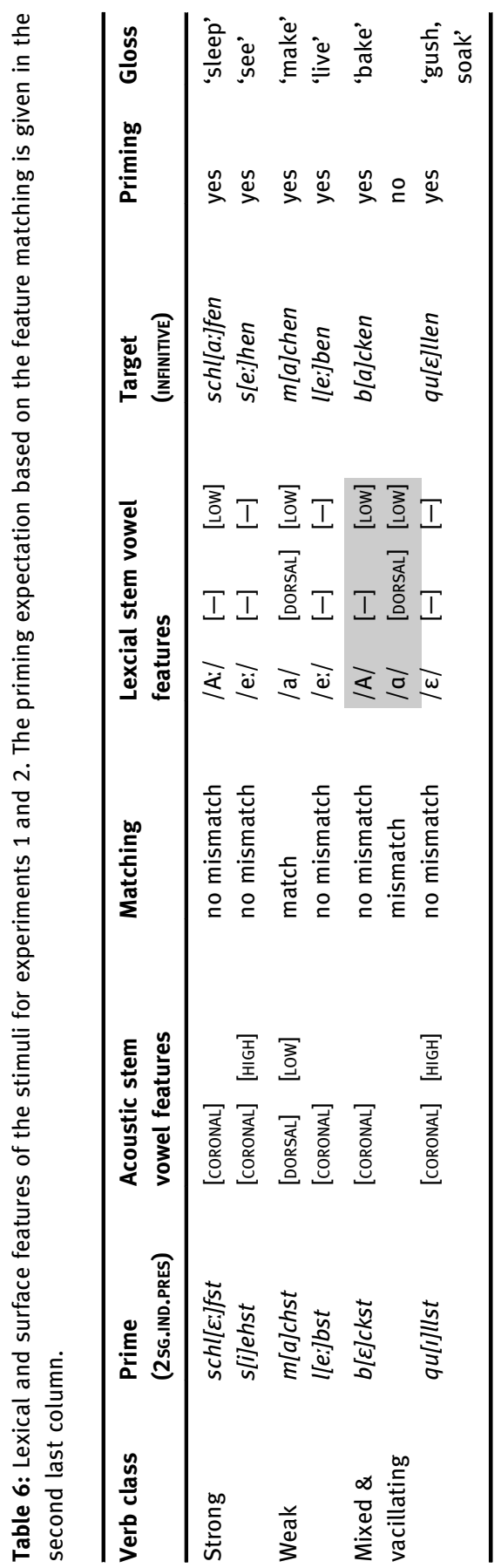


INFINITIVE, the corresponding mixed/vacillating verbs are hypothesised to behave differently. Within the mixed/vacillating verbs, the verbs with $/ a /$ in the INFINITIVE are represented differently from those with $/ \varepsilon /$. For example, the mixed verb backen is assumed to have two verb stems, one with a specified PLACE feature DORSAL (like the weak verb machen) and another which is underspecified (like the strong verb schlafen). In contrast, although quellen vacillates between strong or weak, its phonological representation of the stem remains unchanged, namely underspecified like its strong and weak counterparts. Thus, our expectation was that even though schläfst (strong) would prime its corresponding target schlafen, mixed 2sg bäckst would activate the underspecified representation, but would be unacceptable for the second specified representation. Thus, we expect no morphological priming for the mixed /a/ verbs. However, vacillating quellen would pattern like its strong and weak counterparts, because the stem vowel remains underspecified.

The results confirm our hypotheses. The results are given in Figure 1, where the bars indicate the effect of priming (subtracting the reaction times to the target when the prime was the control or the prime was a related word). The dashed bars indicate, in milliseconds, the amount of priming for morphologically related words and the dotted bars indicate the amount of semantic priming. First, there was no semantic priming in any of the conditions. Second, there was morphological priming in all the conditions except the mixed/vacillating /a/ verbs; the difference between the control and the mixed/vacillating / $/$ / verbs was less than $10 \mathrm{msec}$.

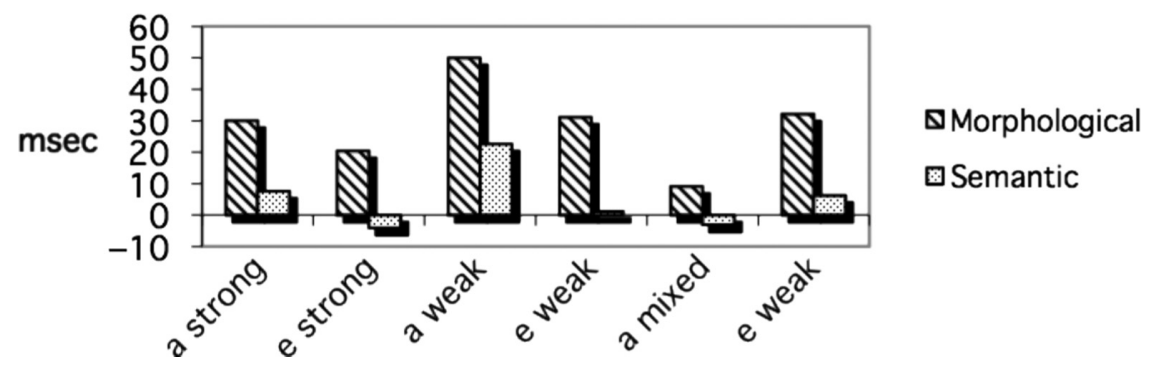

Figure 1: Prime 2sG, Target INFINITIVE.

Thus, in a delayed priming experiment, which allows us to distinguish morphological from semantic relatedness, the weak as well as the strong verbs show priming despite stem vowel alternations in the latter. Both the weak and strong verbs have one representation of the stem for the respective present tense forms. For the strong / $a$ / verbs, vowel height is underspecified in lexical representation, 
and presents no difficulty for the listener: hearing schläfst, the underspecified verb stem is activated and schlafen is primed. However, the mixed and vacillating verbs show a different pattern of alternations. These verbs have two representations, one specified and the other unspecified. Consequently, perceiving a mixed /a/ verb such as bäckst, the specified stem is not activated, causing a decrease in priming.

These priming results confirm the assumptions made here about lexical representations of verbs and, in particular, the asymmetry of the alternations between strong and weak verbs, with derivation going from strong to weak despite the absence of easy-to-see affixation.

\section{Close-up of vacillation}

\subsection{Interim summary}

The conclusion so far, supported by experimental evidence from priming studies, is that although there is no overt affixation or other segmental-additive marking that would identify such verbs as derived, the ways and means of specifying stem vowels in verb inflection suggest that in strong-weak pairs like (8) and (11) the strong verbs are basic and the weak verbs derived in Modern German.

For the pairs in (8) (liegen - legen, fallen - fällen, etc.) the alignment of strong and weak, which is a distinction of inflection classes historically developed from a word-formational distinction of basic and derived, with intransitive and transitive respectively, which is a syntactic (and semantic) distinction, is obvious. For the verbs in (11) (erschrecken, erschreckte/erschrak, etc.) this same alignment yet needs to be demonstrated (Section 4.2). The syntactic-semantic way these vacillating verbs vacillate finds occasional parallels elsewhere in German derivational morphology, which attests to the continuing or even increased potency of this alignment (Sections 4.2.4 and 4.3).

\subsection{Corpus evidence for verb pairs and their uses}

The analysis here is that the vacillating verbs in (11) are effectively pairs of homonymous verbs, one basic and strong and the other derived and therefore weak. We select five of them for demonstrating the syntactic-semantic alignment with intransitive and transitive. These are especially challenging, because 
distinctions here are often rather subtle, as a corpus reveals that is notorious for its unbridled vagaries: the internet; but we find the trend unmistakably confirmed. For the verbs in (11) which we do not examine in detail here the alignments are comparatively straightforward: intransitive meanings and syntactic constructions will trigger or strongly encourage strong inflection of (er-)löschen 'go out, die down', ${ }^{23}$ (er-)bleichen 'turn pale, fade', schmelzen 'become liquefied by heat', wiegen 'have a specified weight', quellen 'gush forth, grow bigger', schleifen 'trail along'; transitive semantics and syntax - 'put out, extinguish, erase, cancel', 'cause to become whiter through exposure to sunlight or chemical means', 'bring about liquid condition by heat, smelt', 'determine the weight', 'cause to grow bigger', 'pull along with effort' ${ }^{24}$ - will trigger or strongly encourage weak inflection.

\subsubsection{Erschrecken}

Among the vacillating verb pairs, perhaps the most telling case for the argument that there is - diachronically speaking, continues to be - an association between strong and intransitive and weak and transitive is that of erschrecken, 'to be frightened, startled' (intransitive) or 'to frighten, startle' (transitive), an animate-argument verb also on the list of Nichols et al. (2004) and thus expected to be detransitivising. Here, as a reminder, are the main distinctive strong and weak forms:

$\begin{array}{llll}\text { PRES IND } & \text { 2SG } & \begin{array}{l}\text { STRONG } \\ \text { erschrick-st } \\ \text { erschrick-t }\end{array} & \begin{array}{l}\text { wEAK } \\ \text { erschreck-st } \\ \text { erschreck-t }\end{array} \\ \text { IMP } & \text { 2SG } & \begin{array}{l}\text { erschrick- } \emptyset \\ \text { erschreck-e }\end{array} \\ \text { PAST IND } & 1 / 3 \text { SG } & \text { erschrak- } \emptyset & \text { erschreck-t-e } \\ \text { PAST SUB } & 1 / 3 S G & \text { erschräk-e } & \text { erschreck-t-e } \\ \text { PRTCP II } & & \text { erschrock-en } & \text { erschreck-t }\end{array}$

23 Comrie (2006: 306) counts löschen - er-löschen as a decausativising pair. This is correct insofar as the prefix er-, functioning as an inchoative, is in this case limited to intransitive (which it is not with most verbs it combines with). On the other hand, since transitive löschen and its other prefix combinations inflect weakly while intransitive er-löschen inflects strongly, this would also be a case of "equipollency" (equally marked) in Comrie's own terms - which in our analysis means causativisation.

24 There is a transitive meaning of schleifen which does require strong inflection, 'grind'. Although of the same origin, strong (older) and vacillating (newer, Middle High German) schleifen have arguably become wholly separate verbs. 
This verb pair is especially instructive because the strong and weak inflections appear to be especially sensitive to subtle nuances of transitivity distinctions, which, as is by now well known, themselves are not a categorical matter.

In fact, the idea of an alignment of strong with intransitive, as in $\mathrm{Er}$ erschrickt/*erschreckt immer bei einem Gewitter 'he is always frightened in a thunderstorm', seems to be immediately faulted by a Google search, which returns a number of seeming counterexamples where erschrecken is inflected strongly despite the verb having two arguments:

(14) a. Verhinderter Räuber erschrickt Bankangestellte.

'Would-be robber frightens bank employee.'

b. Wenn ein Hund einen Radfahrer erschrickt [...]

'When a dog frightens a cyclist...'

c. Kakerlake erschrickt Wetterfrosch. 'Cockroach frightens weather frog.'

d. Indiens Gebrauch von Gehirnscans in den Gerichten erschrickt Kritiker. 'India's use of brainscans in courts frightens critics.'

e. Du erschrickst die Leute mit Deinem Anblick! 'You frighten people with your looks!'

f. Nichts erschrak mich, außer daß der Gesandte Allahs, Allahs Segen und Heil auf ihm, morgens kam, und daß ich ihm anvertraut wurde.

'Nothing frightened me, except that Allah's envoy, Allah's blessing be with him, came in the mornings and I was entrusted to him.'

g. [...] die Vorstellung sie nie mehr anzufassen erschrak mich.

'... the thought never to touch her again frightened me.'

h. Das plötzliche Schwinden seiner Popularität erschrak ihn.

'The sudden decline of his popularity frightened him.'

i. Denn das Ergebnis hat mich wirklich sehr erschrocken.

'For the result really frightened me a lot.'

However, in none of the cases that we have found was the subject of stronglyinflected erschrecken an intentional, responsible, controlling agent acting on a fully affected patient. Rather, the subject here is more of a stimulus than an agent, and the direct object more of an experiencer than a patient. The strong or weak inflection of erschrecken, thus, is sensitive to such a deviation of semantic roles from the transitive prototype, with the syntax still that of a transitive clause.

Further, erschrecken can also be used with what looks like the reflexive pronoun:

(15) Er erschreckt sich (vor Kakerlaken).

'He is frightened ReFL (by cockroaches).' 
However, there is no way this reflexive look-alike can be construed referentially. With verbs of emotional experience such as sich erschrecken, sich fürchten 'to be afraid (of)', or sich freuen 'to be pleased (with)', the reflexive look-alike is more appropriately analysed as a middle marker. Its non-referentiality and lack of argument status would seem to be confirmed by erschrecken again inflecting strongly, in the intransitive manner:
a. Erschrick dich nicht! 'Don't be frightened!'
b. Ich erschrak mich zu Tode. 'I was frightened to death.'

However, for this middle construction of erschrecken a Google search returns a substantial number of weak inflections, as one would rather expect for high transitivity:

(17) a. Sieh hinein in die Augen Deines Pferdes, aber erschrecke Dich nicht vor der Wahrheit.

'Look your horse in the eye, but don't be frightened by the truth.'

b. Affe erschreckt sich vor Spiegelbild.

'Monkey is frightened by its mirror image.'

c. Ich erschreckte mich vor allem, was der Mensch machte [...]

'I was frightened by everything this man did...'

We suggest that this peculiarly indecisive inflectional behaviour of sich erschrecken is due to a conflict of priorities: being semantically intransitive, it should inflect strongly; but being derived, as a middle corresponding to a transitive verb, it should do what derived verbs are expected to do - inflect regularly (= weak).

There is also a quasi-synonymous and less commonly used prefix-less verb schrecken, and it shows the same semantically nuanced pattern of alignment of strong/weak with intransitive/transitive (Sie schrak aus dem Schlaf 'she started up from her sleep' - Er schreckte sie aus dem Schlaf 'he startled her out of her sleep'). ${ }^{25}$ Other combinations of schrecken with prefixes, inseparable (ver'away', only transitive) and separable ( $a b$ - 'off', only transitive; auf- 'up', both intransitive and transitive), follow the same pattern.

25 In hunting jargon schrecken is intransitive and weak; but this is arguably a distinct verb, specifically meaning 'utter cries of panic' (of game) and re-derived from the noun Schreck 'fright'. 


\subsubsection{Hängen}

Another vacillating verb is hängen 'hang', and it is likewise on the list of Nichols et al. (2004) among the inanimate-argument verbs. Used intransitively, it inflects strongly (naturally, its stem vowel does not permit the $e / i$ or umlaut alternation, hence there is no such contrast in the present indicative); used transitively ('to cause to hang'), it inflects weakly:

$\begin{array}{llll} & & \text { STRONG } & \text { WEAK } \\ \text { IMP } & \text { 2SG } & \text { häng- } \emptyset & \text { häng-e } \\ \text { PAST IND } & 1 / 3 \text { SG } & \text { hing- } \emptyset & \text { häng-t-e } \\ \text { PRTCP II } & & \text { ge-hang-en } & \text { ge-häng-t }\end{array}$

Here a true reflexive is possible (especially when hängen combines with inseparable prefix er- or separable prefix auf-), and with the reflexive pronoun referential and an argument, one would expect the transitivity-sensitive inflection to be weak:

(19) a. Er hängte sich auf; Er erhängte sich.

'He hanged himself.'

b. Er hat sich aufgehängt; Er hat sich erhängt. 'He has hanged himself.'

c. Hänge dich doch auf! 'Better hang yourself!'

Seemingly contrary to this expectation, a Google search provides numerous examples of reflexive auf-/er-hängen inflected strongly. They are of three kinds. First, and this is by far the least common kind, there are genuine counterexamples, with indubitably reflexive (auf-/er-)hängen inflecting strongly:

(20) Phädra erhing sich bei der Nachricht von seinem Tode.

'Phaidra hanged herself at the news of his death.'

Second, there are instances where the reflexive shades off towards non-referentiality and non-argument status, and sometimes is even omissible without much semantic difference (note the English translations):

(21) a. Mutter Manon nickte mit dem Kopf, und Mariette hing sich an Colins Arm. 'Mother Manon nodded her head, and Mariette took/hung on to Colin's arm.' 
b. Er zerrte, hing sich an den Strick, er hielt. 'He pulled, hung on to the rope, it held.'

c. Dieser hing sich jeden Morgen seinen Kasten um und ging in die Stadt. 'This man each morning shouldered his box and went to town.'

Third, and it is not surprising that this is the most common kind in internet communication, the subjects of sich (auf-)hängen are not people, but computers or electronic systems:

(22) a. Tom Tom One 1st hing sich auf beim Update - jetzt geht nichts mehr. 'Tom Tom One 1st hung itself up at update - now nothing moves.'

b. Hi, Als ich eben im Internet war hing sich mein pc einfach auf. 'Hi, when I was in the internet just now my PC just hung itself up.'

c. [...] und er lädt und die Punkte bewegten sich für 5 Sekunden und dann hing er sich auf, bzw. das Spiel hing sich auf.

'... and it [the computer] loads and the points moved for 5 seconds and then it hung itself up, or rather the game hung itself up.'

Here the literal meaning of a referent reflexively related to itself has disappeared; meaningwise, such clauses are intransitive, with a predicate that means something like 'become tangled, and therefore stop working, ${ }^{26}$

\subsubsection{Stecken}

A third relevant verb from the list of vacillating verbs, stecken, has a unique history. ${ }^{27}$ Stecken was derived, by means of suffix $-j$, with attendant phonological alterations, from the strong, transitive verb stechen 'to prick, sting'; likewise transitive, stecken used to mean 'to fixate by pricking', and was weak, and still is, as to be expected for a derived verb. Only in early Modern High German did stecken begin to acquire properties of a strong verb: a past tense by ablaut, stak, and the $e / i$ alternation in the present indicative, ich steck-e, $d u$ stick-st, er stick-t; the 2sG imperative (steck-e) and the resultative participle have tended to remain weak (ge-steck-t, only dialectally ge-stock-en). While the old weak forms would be used as transitives, as of old ('to fixate by pricking, to cause to stick'), but would also make inroads into intransitive territory ('to be stuck'), the past tense stak, which is the only strong form to survive in contemporary German (with

26 The English translations in (22) would improve with the reflexives omitted.

27 As documented in the Grimms' Deutsches Wörterbuch, vol. 17 (1919). 
present tense stick-st, stick-t abandoned), always remained confined to intransitive uses:

(23) a. [...] denn ich steckte/stak im Gebüsch.

'... because I was stuck in the shrubbery.'

b. Ich steckte/stak in Schulden. 'I was stuck in debts.'

c. Ich steckte/stak schon in der Vorbereitung meines späteren Buches. 'I was already caught in the the preparation of my later book.'

d. [...] und zwischen beiden Gesichtern steckte/stak ein Kopf. '... and between the two faces a head stuck out.'

(24) a. Sie steckten $/{ }^{*}$ staken seinen Kopf auf eine Lanze. 'They stuck his head on a spear.'

b. Ich steckte/*stak den Brief in den Briefkasten. 'I put the letter in the postbox.'

c. Sie steckten/ ${ }^{*}$ staken ihn ins Gefängnis. 'They threw him into jail.'

d. Er steckte/* stak sich ein Ziel. 'He set himself a goal.'

e. Sie steckten $/{ }^{*}$ staken das Haus in Brand. 'They set the house on fire.'

No transitive stak(en) at all could be found, which is quite a feat, given the grammatical latitude of the internet. Although in the case of stecken the strongweak alternation has come about in a different manner, the morphologicalsyntactic alignment is the same as with the other vacillating verbs: strong = (only) intransitive, weak = transitive (but also intransitive).

\subsubsection{Saugen and pflegen}

In (11) above we only listed verbs where one use was syntactically intransitive; but as the in-depth analysis of actual textual examples shows, it is semantic transitivity that plays an important role in favouring the strong or weak inflection. On such an interpretation of transitivity several further verbs can be considered vacillating rather than simply mixed.

As an example consider saugen 'suck': this verb can inflect strongly or weakly for the past tense (sog-, saug-t-) and the resultative participle (ge-sogen, ge-saug-t); it has a weak causative derivative with umlaut (säugen 'suckle' 
(8a)), which perhaps inhibits umlauting of the basic verb in the regular strong manner. When saugen means 'to draw a liquid into the mouth by creating a partial vacuum through contraction of the muscles of the mouth' (25a), 'to perform a sucking action or sound with one's mouth' (25b), or 'to get filled with liquid' (25c), its conjugation can be strong or weak (with strong preferred in formal speech), regardless of whether the syntax is transitive (25a) or intransitive (25b) or middle (25c); when the meaning is 'to clean with a vacuum cleaner' (25d), strong forms would never be used, even in intransitivised middle constructions $(25 \mathrm{e})$.

(25) a. Das Kind hat die Milch aus der Flasche gesogen/gesaugt. 'The child has sucked the milk from the bottle.'

b. Opa hat an seiner Pfeife gesogen/gesaugt. 'Grandpa has sucked at his pipe.'

c. Der Schwamm hat sich voll Wasser gesogen/gesaugt. 'The sponge has sucked up the water.' (lit. sucked itself full with)

d. Oma hat den Teppich * gesogen/gesaugt. 'Grandma has vacuumed the carpet.'

e. Unser alter Staubsauger hat besser * gesogen/gesaugt. 'Our old vacuum cleaner has vacuumed better.'

Imbibing and ingestive actions, where the patient is literally getting incorporated into the agent and the subject and object referents are thus not fully distinct as a result, are often conceptualised as semantically less transitive than actions of an agent changing the state of a patient that remains external to it (cf. Newman (ed.) 2009).

The strong and weak forms of pflegen - strong PAST pflog-, PARTICIPLE II gepflog-en; weak PAST pfleg-t-, PARTICIPLE II ge-pfleg- $t$ - are distributed along similar lines. The surface syntax is transitive whether pflegen means 'to occupy oneself with' $(26 a)^{28}$ or 'to caringly look after' (26b); but it is only in the latter case that an agent can strictly speaking be said to act on a patient with an eye towards changing its state - and it is here that only weak inflection is possible:

(26) a. Die beiden Damen pflogen/pflegten freundschaftliche Unterhaltung.

'The two ladies cultivated friendly conversation.'

b. Die beiden Damen *pflogen/pflegten einen Kranken.

'The two ladies nursed a sick person.'

28 Archaically, objects could also be in the genitive with this meaning. 
When pflegen is used as a semi-auxiliary corresponding to English used to, the semantics of habitualness is closer to the first, semantically less transitive meaning of the main-verb use; and strong inflection continues to be encountered (as in recent Google hits such as (27)), if increasingly superseded by weak forms.

(27) a. Eine andere Firmenbekannte pflog zu sagen [...]

'Another acquaintance from the firm used to say ...'

b. Er pflog zu ersten Jahren selbst als Dirigent tätig zu sein.

'He in early years used to be active as a conductor himself.'

c. In früheren Zeiten pflogen die biederen Landbewohner den unruhigen Nachwuchs mit einem "Mohnzutz" ruhigzustellen.

'In former times the upright country folks used to silence their unruly offspring with a poppy drink.'

\subsubsection{Vacillation summary}

However haphazardly it has been collected, we confidently conclude from our corpus evidence that the strong or weak inflection of vacillating verbs is sensitive to syntactic-semantic transitivity. With weak as derived by means of a dissociation of phonological feature filling from inflectional morphology in the case of such transparently related verb pairs, transitive continues to be derived from intransitive rather than the other way round.

\subsection{Changing conjugation}

Over the history of German, many strong verbs have become partly or wholly weak, and a few weak verbs have become partly or wholly strong. What we have called vacillation is a sort of mixing where strong and weak inflectional repertoires have become firmly associated with intransitive and transitive syntax and semantics respectively, thereby splitting up single verb lexemes into pairs of homonyms.

There are hints that other inflection class changes were not entirely blind to transitivity distinctions, either.

At no stage of Germanic would all and only intransitive verbs inflect strongly and all and only transitive verbs inflect weakly; nor would all and only transitive verbs be derived by formal means that were to be transformed 
into the weak inflection class markers. The closest fit between morphology and syntax-semantics probably obtained in the old Weak Class 1, with derivational suffix and then inflection class marker $-j$, which in Old High German primarily included transitive; but then, as the weak subclasses merged, more intransitives would end up on the weak side, too. On the strong side, to go by the evidence of Seebold's (1970) massive compilation of some 640 strong stems in panGermanic, intransitives outnumbered transitives by about 2:1. Contemporary (Standard) German has some 150 strong verbs, with roughly the same proportions of intransitives and transitives $(60+$ each) and with some 15 genuine ambitransitives. Comparing such figures, the strong = intransitive and weak $=$ transitive fit would not seem to have improved diachronically. Nonetheless, going through the list of strong verbs that have become partly or wholly weak or have been wholly discontinued since Old High German (some $70+$, judging from Paul (1917: 190-246)), as many as about two thirds are found to have been transitives - significantly increasing the proportion of intransitives in the strong class (which is a closed class, all derived verbs being weak).

The other way round, only a very small number of weak verbs turned strong, including gleichen 'be alike', preisen 'value, praise', weisen 'show, instruct', verderben 'go bad, ruin', schweigen 'be silent', and transiently also winken 'wave', dingen 'hire', and schrauben 'screw'. Percentages would not be meaningful here; but it is worth noting that when gleichen, though derived from adjective gleich 'equal', began to acquire strong forms, this happened first (in the eighteenth century) when the meaning was intransitive (and the morphosyntax too, with the object in the dative rather than accusative), 'be equal', with the transitive meaning 'make equal' only following suit later (Paul 1917: 253254). ${ }^{29}$ In contemporary German, gleichen on its own as well as its prefixal variants, all morphosyntactically and semantically transitive (inseparable vergleichen 'compare', be-gleichen 'pay, settle a bill', separable aus-gleichen 'equalise', an-gleichen 'adjust', ab-gleichen 'check through comparison'), are supposed to inflect strongly; but googling for weak forms returns numerous hits, especially when a direct relation to the adjective gleich is to be highlighted and the morphosyntax and semantics of what would almost seem newly derived verbs are clearly transitive:

(28) a. Ein Klumpen Ton wird dreigeteilt, geschlagen und gegleicht.

'A lump of clay is divided into three, beaten and (the parts) made equal.'

29 Originally, these intransitive and transitive verbs were in different weak subclasses; but by Middle High German times the formal distinction had been levelled. 
b. Während man früher seine persönlichen Daten mit dem Rechner vor Ort abgleichte [...]

'While one used to check one's personal data with the local computer ...'

Historically staggered transitions proceeding along transitivity lines are also observed for changes from strong to weak, and this is what may be behind the systematic vacillations dealt with in detail above. An example is schaffen, continuingly strong (РAST schuf, PAST SUBJUNCTIVE schüf-, PARTICIPLE II ge-schaff-en) in its original meaning 'produce, create', despite its impeccable transitivity. However, when the verb acquired new meanings and their flavour was transitive - such as 'to manage to attain', 'to pass (an exam)', 'to transport from/to a place', 'to finish, exhaust' - then weak inflections were to prevail (PAST schaff-t-, PARTICIPLE II ge-schaff-t).

\section{Umlaut $=$ transitive in German}

Umlaut used to be pure phonology: subject to phonological conditions (e.g., certain consonant clusters could block umlaut), the stem vowel /a/ was fronted to /e/ before / $\mathrm{i}, \mathrm{j} /$ in the following syllable within the same word in West and North Germanic. Later in Old High German and similarly in other West Germanic languages, with much dialectal and diachronic variation, other non-front stem vowels and diphthongs were also fronted when followed by /i, j/, though not all of them equally readily. ${ }^{30}$ For example, umlaut thus regularly occurred in relevant weak verbs of Class 1 , owing to suffix $-j$; but not in the two other weak subclasses with suffixes $-\bar{o}$ and $-\bar{e}$. The umlaut triggers $/ \mathrm{i}, \mathrm{j} /$ themselves were prone to change to schwa or to be dropped in certain environments, and umlaut therefore became phonologically opaque and got morphologised: eventually, umlaut and the allied $e / i$ alternation ended up being parts of exponents together with a suffixal part (with such suffixes as had once contained an umlaut-triggering vowel or where umlaut had been analogically extended, e.g., Fuß 'foot' - Füß-e 'foot-PL', Füß-chen 'foot-DiminUtive') or sole exponents of inflectional and derivational categories (e.g., Garten 'garden' - Gärten 'garden. PL', fall-en 'fall-INF' - fäll-en 'fall.CAUs-INF'). Further, umlaut vowels and

30 Analogous stem vowel alternations were due to following /a/ or $/ \mathrm{u} /$; but these were less momentous. 
diphthongs could come to occur in basic, morphologically simple words: e.g., /ع:/ in Bär 'bear', /y:/ in Tür 'door', /ø:/ in schön 'beautiful', / jy/ in neu 'new'.

There is much controversy about the analysis of umlaut in Modern German and its Germanic relatives. One thing that is not controversial is that there is no DE-umlauting as a morphological exponent or part of one. Whenever there are pairs of morphologically related words without and with umlaut, the one wITH umlaut will always be the DERIVED one. ${ }^{31}$ Now, this asymmetry, which has continued since the times when umlaut was directional in a phonological sense, provides further evidence that there is a deep and strong transitivising current in German.

The evidence here are verbs derived from adjectives or nouns, without affixes or at any rate without suffixes as derivation markers: thus, if there is umlaut, it cannot be triggered by a suffix. For present purposes we regard such basic adjectives and nouns as one-place predicates. Among the derivatives we distinguish between intransitive verbs, designating states or changes of state (typically inchoative, but also related notions, such as 'come to be with', as in Zahn 'tooth' - zahnen 'teethe'), and transitive verbs, designating causations of changes of state (and related notions, like 'using an instrument to effectuate a change of state', as in Kamm 'a comb' - kämmen 'to comb', or 'cause someone/ something to be without', as in Kopf 'head' - köpfen 'behead'). Being derived, all such verbs are weak. Sometimes they show umlaut or also an $e / i$ alternation, and sometimes they don't - and this pattern is not random. The following listings are divided up into eight sets - (29)-(36), as explained presently - by how the umlaut/no umlaut patternings are distributed over intransitive and transitive, and also by the absence of a derivative in one or the other column. Each group is subdivided into animate-argument (a) and inanimate-argument (b) verbs, with regard to derived intransitive verbs; there is some arbitrariness here because several verbs are equally applicable to animates and inanimates. These listings are fairly comprehensive as regards adjectival bases, with the language having not much more than 100 basic adjectives altogether; derivatives with noun bases could be multiplied, but this would only confirm the pattern as recognisable from (29)-(36). ${ }^{32}$

31 If there are any contenders for counterexample status it is certain conversion pairs of nouns and verbs in German. Usually it is clear on all sorts of grounds whether the noun is derived (e.g., kaufen 'to buy' - Kauf 'a buy') or the verb is derived (e.g., Haus 'a house' - hausen 'to be housed'). However, in a few pairs, where the noun does not designate a person or thing, the basicness of (unumlauted) nouns and the derivedness of (umlauted) verbs is harder to demonstrate: e.g., Traum 'a dream' - träumen 'to dream', Kuss 'a kiss' - küssen 'to kiss'.

32 For more extensive and semantically more highly differentiating surveys see Kühnhold \& Wellmann (1973) and Fleischer et al. (1992). 
(29) BASIC A/N

a. stumpf 'blunt, dull'

$$
\text { dumm 'stupid' }
$$

matt 'exhausted'

roh 'brutal'

Hunger 'hunger'

b. dunkel 'dark'

fett 'fat, greasy'

flach 'flat'

trocken 'dry'

gar 'cooked, done'

Staub 'dust'

(30) BASIC A/N

a. gesund 'healthy'

alt 'old'

arm 'poor'

karg 'sparse'

stumm 'dumb, silent'

blond 'blond'

toll 'wild, mad'

fromm 'pious'

schlaff 'slack'

Ruhe 'rest, quiet'

Zahn 'tooth'

Kalb 'calf'

b. grau 'grey'

blass 'pale'

starr 'stiff'
DERIVED INTRANSITIVE V

ab-stumpf-en 'become dull'

ver-dumm-en 'become

stupid'

er-matt-en 'languish'

ver-roh-en 'become a brute'

hunger-n 'feel hungry'

dunkel-n 'darken'

fett-en 'be greasy'

ver-flach-en 'get flat, superficial'

trockn-en 'dry'

gar-en 'cook'

staub-en 'be dusty'
DERIVED TRANSITIVE V

ab-stumpf-en 'make

dull'

ver-dumm-en 'make

stupid'

er-matt-en 'wear

down'

ver-roh-en 'brutalise'

hunger-n 'hunger

overcomes s.o.'

ver-dunkel-n

'darken'

fett-en 'grease'

ab-flach-en 'flatten'

trockn-en 'dry'

gar-en 'cook'

(ab-)staub-en 'clear of dust ${ }^{33}$

$\begin{array}{ll}\text { DERIVED INTRANSITIVE V } & \text { DERIVED TRANSITIVE V } \\ \text { gesund-en 'recuperate' } & - \\ \text { alt-ern 'grow old' } & - \\ \text { ver-arm-en 'become } & - \\ \text { impoverished' } & \\ \text { karg-en 'be sparing' } & - \\ \text { ver-stumm-en 'go silent' } & - \\ \text { er-blond-en 'turn blond' } & \\ \text { toll-en 'romp' } & - \\ \text { fromm-en 'avail' } & - \\ \text { er-schlaff-en 'slacken' } & - \\ \text { ruh-en 'rest, cease' } & - \\ \text { zahn-en 'teethe' } & - \\ \text { kalb-en 'calve' } & - \\ \text { grau-en 'be grey, dawn' } & - \\ \text { ver-blass-en 'fade' } & - \\ \text { er-starr-en 'stiffen' } & -\end{array}$

33 But see also (be-)stäub-en at (33b). 


\author{
faul 'rotten, lazy' \\ welk 'limp' \\ nah 'near'
}

faul-en 'rot' welk-en 'wilt" nah-en 'approach'

$$
\text { BASIC A/N }
$$

\section{DERIVED TRANSITIVE $\mathrm{V}$}

a. ?

b. rund 'round' straff 'tight' arg 'severe' eng 'narrow' fern 'far' leer 'empty' -

(32) BASIC A/N

a. lahm 'lame' krank 'ill' taub 'deaf' stark 'strong’ sauer 'sour' wach 'awake' Futter 'fodder'

Durst 'thirst'

Recht 'law'

recht 'right'

Haft 'adhesion, liability, custody' Affe 'monkey, ape'

Wasser 'water'

-
-
-
-
-

$$
\text { DERIVED INTRANSITIVE V }
$$$$
\text { lahm-en 'limp' }
$$$$
\text { krank-en 'suffer from' }
$$$$
\text { er-taub-en 'go deaf' }
$$

er-stark-en 'recover strength' ver-sauer-n 'go stale' wach-en 'be awake' futter-n 'eat, stuff oneself' durst-en 'feel thirsty, have a strong desire' recht-en 'dispute'

haften 'stick, cling, be liable'

herum-aff-en 'monkey around' wasser-n 'land on water'
?

rund-en 'make round' straff-en 'tighten' ver-arg-en 'take amiss' be-eng-en 'make narrow' ent-fern-en 'remove' leer-en 'empty' DERIVED TRANSITIVE V lähm-en 'paralyse' kränk-en 'hurt' be-täub-en 'anaesthetise' stärk-en 'strengthen'

säuer-n 'acidify' weck-en 'wake up' fütter-n 'feed' dürst-en 'be thirsty'34 richt-en 'get right, fix, pass judgment'

heften 'fasten' nach-äff-en 'ape, mimic' wässer-n 'water'

34 Only the umlauted verb takes an accusative object, if in an impersonal construction: mich dürstet 'I am thirsty'. Compare with hungern above at (30a), where none of these two syntactic uses has umlaut. 
Ruck 'jerk, jolt'

Zuck 'sudden pull or jerk' (expressive)

b. prall 'firmly rounded'

klar 'clear'

kalt 'cold'

blau 'blue'

laut 'loud'

Dampf 'steam'

Staub 'dust'

(33)

$\begin{array}{ll}\text { BASIC A/N } & \text { DE } \\ \text { a. } z \text { zahm 'tame' } & - \\ \text { schwach 'weak' } & - \\ \text { bloß 'bare' } & - \\ \text { tot 'dead' } & - \\ \text { jung 'young' } & - \\ \text { gram 'sorrowful' } & - \\ \text { Gruß 'greeting' } & - \\ \text { Kopf 'head' } & - \\ \text { Kamm 'comb' } & -\end{array}$

b. ganz 'whole' falsch 'false' sauber 'clean' warm 'warm' los 'loose' hart 'hard' scharf 'sharp' glatt 'smooth' platt 'flat' krumm 'crooked' - ruck-en 'move about with jerks ${ }^{35}$

zuck-en 'jerk, twitch'

prall-en 'bounce'

auf-klar-en 'become clear'

er-kalt-en 'go cold'

blau-en 'be/get blue'

laut-en 'sound'

dampf-en 'steam'

staub-en 'be dusty' rück-en 'move something from its position with a jerk' zück-en 'pull out with a swift movement' prell-en 'shove, bump'

klär-en 'clarify'

(sich) er-kält-en 'catch a cold'

(ver-)bläu-en 'beat up' läut-en 'ring' dämpf-en 'steam, dampen' (be-)stäub-en 'powder, pollinate'

DERIVED TRANSITIVE $\mathrm{V}$

zähm-en 'tame' schwäch-en 'weaken' (ent-)blöß-en 'bare' töt-en 'kill' ver-jüng-en 'rejuvenate' gräm-en 'cause grief' grüß-en 'greet' köpf-en 'behead' kämm-en 'comb' er-gänz-en 'complement' fälsch-en 'falsify' säuber-n 'clean, purge' wärm-en 'warm up' lös-en 'separate' härt-en 'harden' schärf-en 'sharpen' glätt-en 'smoothen' plätt-en 'iron' krümm-en 'bend'

35 But see also rücken at (37a). 


kurz 'short'
lang 'long'
hohl 'hollow'
hoch 'high'
braun 'brown'
schwarz 'black'
gut 'good'
Ruhm 'fame'
Farbe 'colour'
Hut 'hat, care'

(34)

\begin{tabular}{ll}
\multicolumn{1}{c}{ BASIC A/N } & DERIVED INTRANSITIVE V \\
a. blind 'blind' & er-blind-en 'go blind' \\
b. wahr 'true' & $\begin{array}{l}\text { sich be-währ-en 'prove } \\
\text { oneself' } \\
\text { währ-en 'last' }\end{array}$
\end{tabular}

(35)

\begin{abstract}
BASIC A/N
\end{abstract}
a. Nest 'nest'

b. gelb 'yellow' DERIVED INTRANSITIVE V

nist-en 'build/use a nest'
kürz-en 'shorten'
läng-en 'lengthen'
höhl-en 'hollow out'
er-höh-en 'raise, increase'
bräun-en 'make brown, tan'
schwärz-en 'blacken'
ver-güt-en 'compensate, pay'
rühm-en 'praise'
färb-en 'colour'
hüt-en 'guard'
DERIVED TRANSITIVE V
blend-en 'blind'
be-wahren 'keep'
wahr-en 'keep, maintain'
DERIVED TRANSITIVE V

$\begin{array}{lll}\begin{array}{l}\text { BASIC A/N } \\ \text { a. rot 'red' }\end{array} & \begin{array}{l}\text { DERIVED INTRANSITIVE V } \\ \text { er-röt-en 'blush' }\end{array} & \begin{array}{l}\text { DERIVED TRANSITIVE V } \\ \text { röt-en 'redden' } \\ \text { Ruck 'jerk, jolt' } \\ \text { zürn-en 'be angry'en 'make angry' } \\ \text { rück-en 'move over' } \\ \text { rück-en 'move something from } \\ \text { its position with a jerk' } \\ \text { b. nass 'wet' }\end{array} \\ \begin{array}{l}\text { näss-en 'make wet' } \\ \text { netzen 'open 'moisten' }\end{array} \\ \begin{array}{l}\text { Sturm 'storm' } \\ \text { kühl 'cool' }\end{array} & \begin{array}{l}\text { öffn-en 'open' } \\ \text { stürm-en 'be stormy' } \\ \text { (ab-)kühlen 'cool } \\ \text { down' }\end{array} & \begin{array}{l}\text { öffn-en 'open' } \\ \text { stürm-en 'take by storm' } \\ \text { kühlen 'cool' }\end{array}\end{array}$

ver-gilb-en 'become yellow, fade' -

The striking asymmetry that emerges from this survey is that whenever there is umlaut (or $e / i$ alternation) with an intransitive derivative, then there is also umlaut (or $e / i$ alternation) with a corresponding transitive derivative. It is possible, and not uncommon, for intransitive and transitive derivatives to either both lack (29) or to both have (36) umlaut. (Kühl is an example of the basic adjective itself having umlaut, here placed in group (36); but (29) would be appropriate, too.) If there is a gap in the derived transitive column and the derived intransitive verb is lacking umlaut, as in group (30), both unumlauted 
and umlauted derived transitive verbs, if there were any, would conform to the asymmetric pattern. A gap at derived intransitive and no umlaut with derived transitive verbs, as in (31), is not really at odds with the implicational generalisation, either: derived intransitive verbs, if existing, could be lacking umlaut, too; but this is a very small and unproductive group anyhow. Equally small and unproductive is group (35): umlaut or rather $e / i$ alternation with derived intransitive verbs and a gap at derived transitive; if existing, derived transitive verbs would have to have umlaut or $e / i$ alternation in order not to offend. The most populous groups by far are (32) and (33): umlaut with derived transitive verbs and no umlaut with derived intransitive verbs (32), or derived intransitive verbs missing (33); regardless of whether these gaps were to be filled by unumlauted or umlauted intransitives, the generalisation would stand. The only real problem is the pattern in (34): umlaut or $e / i$ alternation with derived intransitives, no umlaut or $e / i$ alternation with derived transitives. But there are very few, if any, pairs of derived verbs impeccably instantiating this pattern. In the case of erblind-en - blenden, the basic adjective itself has /i/; in the case of basic wahr, the derivational relatedness of both intransitives and transitives is semantically rather opaque. ${ }^{36}$

The adjectives and nouns in the left-hand column of (29)-(36) are basic; but what is the derivational relationship between intransitive and transitive verbs

36 The Swiss Alemannic variety of Kerenz in Kanton Glarus, famously described by Jost Winteler, has the most extensive and systematic alignment between no umlaut and intransitive and umlaut and transitive among weak verbs we are aware of: vis-à-vis the Standard German pattern just delineated, here pattern (32) is effectively generalised. The former weak subconjugation in the Kerenz dialect continues the Old High German weak subclasses with suffixes $-\bar{o}$ and $-\bar{e}$, not triggering umlaut but retained as schwa; the latter weak subconjugation continues the old weak class with suffix $-j$, itself deleted but continuing to cause umlaut - with overt differences in 2nd/3rd singular indicative present, subjunctive, and past tense (Winteler 1876: 154-158, retaining his transcription and translations, with the examples reproduced here 3sG.IND. PRES):

(i)

\begin{tabular}{|c|c|c|}
\hline & INTRANSITIVE & TRANSITIVE \\
\hline 'full' & foll-ęt 'wird voll' & füll-t 'füllt' \\
\hline ‘cool’ & xu\&l-ęt 'wird kühl' & $x \ddot{u} \& l-t$ 'kühlt' \\
\hline ‘tame’' & tsam-êt 'wird zahm' & tsem-t 'zähmt' \\
\hline ‘empty’ & l\&s-êt 'wird leer' & $l_{\underline{\alpha} \mathbf{r}-t}$ 'macht leer' \\
\hline 'stick, glue' & $\overline{x l e b}$-ẹt 'klebt' (state) & $\overline{x l} \& \ddot{u ̈ b}-t$ 'klebt' (action) \\
\hline 'milk’ & mellx-êt 'nimmt an Milch zu' & millx-t 'melkt' \\
\hline anger' & feor-t\&ub-et 'wird zornig’' & fer-töüb-t 'macht zornig' \\
\hline
\end{tabular}


based on them? One possibility is that both are derived, in one step each, from basic adjectives or nouns. Alternatively, transitive verbs could be derived from intransitive verbs or vice versa in two-step derivations. Both directions of derivation would in principle be semantically viable, with the conceptual operations required being respectively those of valency-augmentation with causativisation and valency-reduction with decausativisation. What potentially militates against this latter, derivationally more complex option are derivational gaps. (30) above is a reasonably productive group; and with transitive verbs missing, it would be odd for intransitive verbs to be derived via such unattested intermediate stages. Analogously, in (33), which is an even more productive group, lots of transitive verbs would have to be derived via unattested intransitive verbs. Furthermore, occasionally the meanings of corresponding intransitive and transitive verbs are such as to preclude a derivation of one from the other (e.g., er-taub-en - be-täuben, wasser- $n$ - wässer-n (32a)) - although these may be individual idiosyncrasies attendant on lexicalisation.

The strongest argument against deriving intransitive verbs from transitive verbs in such sets as those above is that, manifestly in the large group (32), this would require de-umlauting as the exponent of a morphological operation which is otherwise unheard of in German. In its morphologised form, umlaut thus implies that for verbs derived from adjectives or nouns directly, or via a stage of verbalisation, the direction of derivation is that of transitivisation, not detransitivisation. Which is not to rule out that there is also productive derivation of intransitives, like those in the middle column of (29)-(36) - only that they are not derived from transitives.

\section{Synchrony, diachrony, and acquisition}

\subsection{Typology and pertinacity}

To sum up, on the parameter of Basic Valence Orientation German emerges as being typologically mixed. On the one hand, it shows a detransitivising or indeterminate disposition through syntactic and lexical middle marking or verb lability, as observed by Nichols et al. (2004). On the other hand, there is also a strong and deep current of transitivisation when valency alternations are expressed morphologically. This transitivising morphological asymmetry is not affixal, but is implemented through phonology: alternations of stem vowels of the ablaut type (in relation to non-alternation as in weak verbs) as well as of the umlaut type have directionality, no less resolutely than the absence or presence 
of easy-to-spot affixes - when examined through the microscope, focused on abstract lexical representations and scrutinising ostensibly messy corpora.

These counter-currents in the contemporary language represent different historical layers: transitivisation continues an old morphological pattern, upon which detransitivisation in particular by means of middle marking has later been superimposed. (Arguably, orientational indeterminateness owing to verb lability has also been gaining ground historically in German.) Large parts of the relevant vocabulary, as surveyed above, combine these two layers of derivation in opposite directions. To exemplify, with the doubly derived intransitives chosen here from among the lexical rather than syntactic middles $(\mathrm{s}=$ strong, $\mathrm{w}=$ weak, $\mathrm{v}=$ vacillating verb, $\mathrm{A}=$ adjective, $\mathrm{N}=$ noun):

\begin{tabular}{|c|c|c|}
\hline BASIC LOWER-VALENCY $\rightarrow$ & TRANSITIVISED $\rightarrow$ & DETRANSITIVISED \\
\hline & ken $(\mathrm{w})$ & sich erschrecken (w or v) 'be \\
\hline frightened' & 'frighten' & frightened' \\
\hline sitzen (s) 'sit' & setzen $(\mathrm{w})$ 'set' & sich setzen (w) 'sit down, settle' \\
\hline liegen (s) 'lie’ & legen (w) ‘lay’ & $\begin{array}{l}\text { sich legen (w) 'lie down, } \\
\text { subside' }\end{array}$ \\
\hline $\begin{array}{l}\text { fahren (s) 'drive, } \\
\text { ride' }\end{array}$ & $\begin{array}{l}\text { führen }(\mathrm{w}) \text { 'lead, } \\
\text { drive' }\end{array}$ & sich führen $(\mathrm{w})$ 'conduct oneself' \\
\hline winden (s) 'wind' & wenden (v) 'turn' & $\begin{array}{l}\text { sich wenden (w) 'turn out, } \\
\text { change' }\end{array}$ \\
\hline haben (irreg.) 'have' & geben (s) 'give’ & sich geben (s) 'behave, subside' \\
\hline sehen (s) 'see' & zeigen $(\mathrm{w})$ 'show' & sich zeigen $(\mathrm{w})$ 'turn out' \\
\hline sehen (s) 'see' & $\begin{array}{l}\text { sehen lassen (s s) } \\
\text { 'let see' }\end{array}$ & $\begin{array}{l}\text { sich sehen lassen (s s) 'drop by, } \\
\text { be impressive' }\end{array}$ \\
\hline leer (A) ‘empty’ & $\begin{array}{l}\text { leeren }(\mathrm{w}) \text { 'make } \\
\text { empty' }\end{array}$ & sich leeren $(\mathrm{w})$ 'become empty' \\
\hline voll (A) 'full' & füllen (w) 'fill' & sich füllen (w) 'get full' \\
\hline fern (A) 'far' & entfernen $(\mathrm{w})$ & sich entfernen (w) 'depart' \\
\hline glatt (A) 'smooth' & $\begin{array}{l}\text { 'remove' } \\
\text { glätten }(\mathrm{w})\end{array}$ & sich glätten (w) 'smooth out' \\
\hline Hut (N) 'hat, c & hüten (w) 'guard' & sich hüten (w) 'beware of' \\
\hline
\end{tabular}

This current typological mixture is of particular diachronic significance insofar as the older transitivising inclination has proved remarkably pertinacious: it has managed to long outlive the loss of the actual affixal valency-increasing morphology of Common Germanic and it has been able to hold its own against more recent detransitivising competition. The original Germanic and partly older 
affixes for deriving transitives have in the meantime changed function, turning into markers of verbal inflection classes, and disappeared. It is only their associated, or dissociated, segmental phonological alternations or non-alternations which have survived over some two millennia. Their asymmetric distributions, which have weathered sound changes and were thrown into sharper relief through analogical redistributions, continue to transparently signal over large parts of the vocabulary that higher-valency is derived from basic lexical lowervalency rather than vice versa.

Looking back yet further, the original Basic Valence Orientation of IndoEuropean is harder to ascertain. For Nichols (1982) it was transitive, with morphology and argument-alternating syntax overwhelmingly detransitivising. However, so far as it can be reliably reconstructed, Proto-Indo-European must have had an equal share of intransitive and transitive verbal roots, and in this sense was mixed: some 570 of each have been collected in Rix et al. (1998), the most comprehensive and authoritative compilation to date. According to this source, morphological transitivisation was far outweighing detransitivisation: Rix et al. (1998: 22-23, 25) count 494 primary stems with causative-iterative suffixes -éie/o- and -ie/o-, but only 58 fientives (change-of-state stems, suffix $\left.-(\hat{e}) h_{1^{-}}\right)$and 94 essives (state stems, suffix $\left.-h_{1} i_{e} e^{-}\right) .{ }^{37}$ Early Germanic was to retain this Indo-European bias, if we accept it as real: deriving verbs, for the weak conjugation, would usually produce transitives; and only the weak subclass IV (-nă/-nō verbs), hardly attested in West Germanic and not especially productive in East and North Germanic either, arguably had decausative function. Within Germanic only English appears to be really special, having developed a preference for ambitransitive (labile, equipollent) verbs; Old English is generally assumed to have been predominantly transitivising, but this has recently been questioned by van Gelderen (2011), who sees early traces of indecision of orientation. $^{38}$

37 The second edition of Lexikon der indogermanischen Verben (2001) was not available to us at the time of counting: spotchecks since then suggest that the differences are not dramatic. Also see Kulikov (2009) for an overview, and Luraghi (2012) specifically for Hittite. The middle voice became the chief vehicle of detransitivisation in later Indo-European. Gianollo (2014) is an instructive case study of such developments from Classical to Late Latin.

38 Ottosson (2013) argues that Gothic, Old Norse, as well as Old High German early changed from valency-increasing to valency-decreasing, by way of middle constructions and a boost for weak class IV. But this is unconvincing, at least for German and West Germanic as a whole, where an overwhelming amount of evidence for directedness of derivation of the kind adduced here would have to be ignored. 
Elsewhere, Comrie (2006) finds that a causativisation preference has been diachronically very stable in other families, too, namely Semitic and Uralic; ${ }^{39}$ similarly Narrog (2009) and, despite certain reservations, Frellesvig \& Whitman (2012) for Japanese. Comparing two close Northeast Caucasian relatives, Creissels (2014) finds many more transitivisations among the diagnostic pairs of Nichols et al. (2004) in Akhvakh than in Avar; but where Avar does not transitivise it does not detransitivise either, but rather has verbs categorised as ambitransitive. Allowing for shorter-term encroachments of indeterminateness through verb lability, ${ }^{40}$ all this goes to corroborate the original hypothesis of Nichols (1982) that basic intransitivity or transitivity is a deep-seated conservative trait shedding light on the history of languages even after millennia of other changes.

An idea aired by Nichols (1993) is that causativisation is the general and normally time-stable preference - one that can be interfered with, however, through contact with a dominant language of different orientation. The IndoEuropean languages of Europe are supposed to have turned to decausativising over recent millennia, largely owing to their revival of middle constructions. With orientation so stable, it would need intense and prolonged contact to succumb to re-orientation - as, among Uralic, Hungarian seems to have done; among Semitic, Maltese probably didn't. For German(ic) it is not obvious that contact has played a role in the superimposition of detransitivisation upon the deeper lexical layer of transitivisation.

\subsection{Learning basic lexical orientation}

To the extent that they are not inherited, lexicons and grammars are acquired from experience. A general question about lexical typologies of a holistic kind, as advocated by Nichols et al. (2004) as well as ourselves, is how it is that constraints on or dispreferences in crosslinguistic variation can be effective. How are learners of a language supposed to organise their mental lexicons and grammars so as to be in line with across-the-board constraints or dispreferences like those envisaged here? And how are these organising options supposed to remain stable from generation to generation of language learners?

39 For Maltese, one of the Semitic languages found by Comrie to be continuingly causativising despite close contacts with Indo-European Italian, Spagnol (2011) argues for greater instability, with directed derivation increasingly replaced by undirected.

40 However, see Heidinger (2014) for a case study of persistently detransitivising middle marking in competition with verb lability in the history of French. 
For the parameter at issue, Basic Valence Orientation, learners will crucially have to figure out two things: (i) the basic valency characteristics of each predicative lexical item of the language, along with its lexical meaning, form, and other categorial specifications; (ii) the derivational programmes which the language offers. There will be some complementarity here insofar as derivation will be especially useful for things that do not already come with basic expressions. (Thus, if all basic verbs were intransitive, this would preempt the need for detransitivising morphology or syntax.) Typological constraints or dispreferences, then, come about when separate choices are not made independently, but one choice is dependent on another. Here, the valency characteristics of basic predicates are not fully determined by meaning; and the derivational programmes can also include valency-augmentation as well as valency-reduction. Thus, many choices need to be made, and the question is whether the choice for one predicate is dependent on that for another.

To sketch an informal learning algorithm, this seems to be how wholelanguage Basic Valence Orientation can come about, then: when a learner determines that onE basic predicate is intransitive or transitive, s/he will set the valency specification of EVERY OTHER predicate in the language $s /$ he is yet to learn analogously. The derivational programme should be able to accommodate either choice, providing for transitivisations or detransitivisations as required.

Conscientious learners will notice, however, that typological profiles are rarely consistent especially in lexical matters: when some basic predicates they have already learnt are intransitive and others transitive, they cannot reliably generalise from one predicate to all others they may yet encounter. If they give up all hope, they will expect to have to specify valency for each new basic predicate individually; if they retain some hope, they will assume one setting as the default, overwritten only in the face of strong evidence to the contrary; or they will think strategically and seek to infer valency characteristics from other properties of basic predicates independently needed for other grammatical purposes.

This last is effectively what Nichols et al. (2004) must be assuming about learners. Their strategic learners go for semantics and divide up verbs into animate- and inanimate-argument verbs or rather concepts, as distinguished in (1a) and (1b) above: for the latter subgroup, they generalise in favour of a basic transitive setting everywhere, regardless of the particular language they are learning; for the former subgroup, they wait what the language to be learnt holds in store, and from the valency specification of one basic predicate - lowervalency or higher-valency - they generalise over all others.

Such learners would not be able to learn German, or would not have been able to change earlier German(ic) to what it is like now. In critical examples 
above we have followed the division of Nichols et al. (2004) into animate- and inanimate-argument verbs, but the directions of derivation show little correlation with this grouping. It is only with vacillating verbs (11), which we analyse as instances of transitivisation, that one semantic group - inanimate-argument clearly predominates. But then, for inanimate-argument verbs the universal preference is supposed to be detransitivisation according to Nichols et al. (2004).

Elsewhere other strategies have been suggested which also rely on semantic or conceptual distinctions. Both inchoatives (lower-valency) and causatives (higher-valency) are about changes of state, and a distinction has been suggested between such changes of state for which it is more usual to occur spontaneously or to be brought about through the instigation of some causal force. Thus, attempts have been made to subdivide verbs (or concepts) into ones designating "internally" and "externally caused" events (Levin \& Rappaport Hovav 1995, Koontz-Garboden 2009), or into "automatic" and "costly" verbs (Haspelmath 1993, 2008; Comrie 2006). The economic learning strategy here would be to take as basic what is more common and to reserve extra derivational effort for what is less common: for changes of state which more commonly occur spontaneously it would be more economical to be basically intransitive; for changes of state which more commonly occur with external instigation, it would be more economical to be basically transitive. Adopting this strategy, and assuming that internal and external causations are culturally largely invariant, all learners of all languages should come up with the same valency specifications for translation-equivalent predicates: Basic Valence Orientation accordingly would not be a parameter for variation between (whole) languages, but for variation between individual predicates, with no predicate or concept itself varying across languages.

Could such economical learners have learnt or shaped German? Hardly. It is probably viable to set apart some changes of state as almost inevitably externally caused. For example, getting assassinated or beheaded is not something that normally comes about spontaneously, "by itself". All the same, these very changes of state that need an agent or some causal force are not expressed through basic transitive verbs in German (and lots of other languages, Germanic and other), but through transitive verbs which are derived from nouns: er-morden 'murder', köpf-en, ent-haupt-en 'be-head'. Then, where would a learner draw the line between "less common" and "more common" occurrences with or without external cause? This is a cline, and when learners are guided by textual frequencies, the differences between intransitive and transitive occurrences will often be minute, not pointing to a divide clear enough to firmly establish a subclassification of predicates. Even for those predicates or concepts that have been mentioned among the extremes of spontaneity - boiling, freezing, drying, 
waking up, sinking, melting, turning (Haspelmath 1993, 2008; Comrie 2006) assumptions about internal/external causation will greatly depend on context and cultural and atmospheric circumstances, again militating against acquiring a robust lexical subclassification. Two verb pairs high on the spontaneity hierarchy of Haspelmath and Comrie, wachen - wecken 'wake up' (34a) and schmelzen 'melt', inflecting strongly or weakly (11b), happen to be among those where we have argued for transitivisation; but the overall picture of German transitivisations is no diptych of two kinds of events that would "normally" happen or not happen von selbst and be accordingly transitivised or detransitivised. ${ }^{41}$ Effectively, a Haspelmath-Comrie learner of German would have to specify valencies predicate by predicate, not the most economic learning procedure.

The learners of lexically most basic valence orientation that we envisage would not be semantic strategists and lose battles with more than chance frequency or often be at a loss how to even do battle. Their strategy would be "win some, lose some", and through unconditionally setting the formal default at transitivisation and countenancing detransitivisation only when forced to, they would be maximising the wins and minimising the losses. For a language like German, they would be especially encouraged by the peculiar way the phonology of ablaut and umlaut has come to be implicated with verbal inflection classes and transitivity. With this sort of sound grounding, Basic Valence Orientation is, perhaps, even stabler than when based on the elusive objects that affixes or reflexive look-alikes are.

Acknowledgments: An earlier version of this article was presented at ALT 8, Berkeley, 23-26 July 2009, and on many occasions hence. Thanks to audiences, correspondents, and several (three?) pertinacious $L T$ reviewers for keeping us rethinking and rewriting even when our own pertinacity was flagging, and to Johanna Nichols for much-appreciated continuing encouragement and advice.

Abbreviations: $1 / 2 / 3=1 \mathrm{st} / 2 \mathrm{nd} / 3 \mathrm{rd}$ person; CAUS = causative; IMP = imperative; $\mathrm{IND}=$ indicative; $\mathrm{INF}=$ infinitive; $\mathrm{PL}=$ plural; $\mathrm{PRES}=$ present; $\mathrm{PRTCP}=$ participle; $\mathrm{SG}=$ singular; SUB $=$ subjunctive.

41 No doubt there can be semantic grounds for determining directions of derivation; but then the semantic classifications will be robust. An example are adjectives and abstract nouns (Plank 2009). There is no unique direction of derivation here either: adjective from noun (e.g., English virtu-ous from virtue) or noun from adjective (e.g., nobil-ity from noble) are both possible. But such disorder is only found for human propensities; for other well-delimited subclasses, such as size/dimension, speed, or age, the direction is predictably from adjective to noun (wide - width, slow - slow-ness, old - old-ness/age, etc.). 


\section{References}

Akinlabi, Akinbiyi. 2011. Featural affixes. In Marc van Oostendorp et al. (eds.), Companion to phonology, 1945-1971. Oxford: Wiley-Blackwell.

Bittner, Andreas. 1996. Starke schwache Verben - schwache starke Verben: Deutsche Verbflexion und Natürlichkeit. Tübingen: Stauffenburg.

Bittner, Andreas \& Klaus-Michael Köpcke. 2007. Überlegungen zur Repräsentation grammatischen Wissens am Beispiel der Verbmorphologie des Deutschen. In Claudio di Meola et al. (eds.), Perspektiven Zwei: Akten der 2. Tagung Deutsche Sprachwissenschaft in Italien, 3-15. Roma: Istituto Italiano di Studi Germanici.

Comrie, Bernard. 2006. Transitivity pairs, markedness and diachronic stability. Linguistics 44. 303-318.

Comrie, Bernard \& Maria Polinsky (eds.). 1993. Causatives and transitivity. Amsterdam: Benjamins.

Creissels, Denis. 2014. P-lability and radical P-alignment. Linguistics 52. 911-944.

Cysouw, Michael. 2008. Generalizing scales. In Marc Richards \& Andrej Malchukov (eds.), Scales, 379-396. Leipzig: Institut für Linguistik, Universität Leipzig.

Cysouw, Michael. 2010. Semantic maps as metrics on meaning. Linguistic Discovery 8. 70-95. Fleischer, Wolfgang, Irmhild Barz, with Marianne Schröder. 1992. Wortbildung der deutschen Gegenwartssprache. Tübingen: Niemeyer.

Frellesvig, Bjarke \& John Whitman. 2012. The historical source of the bigrade transitivity alternations in Japanese. Paper at the NINJAL International Symposium on Valency Classes and Alternations in Japanese, 2012. http://www.academia.edu/4417592/

The_Historical_Source_of_the_Bigrade_Transitivity_Alternations_in_Japanese

Ghini, Mirco. 2001. Asymmetries in the phonology of Miogliola. Berlin: Mouton de Gruyter.

Gianollo, Chiara. 2014. Labile verbs in Late Latin. Linguistics 52. 945-1002.

Grimm, Jacob \& Wilhelm Grimm. 1919. Deutsches Wörterbuch, Vol. 17: Sprecher - Stehuhr. Leipzig: Hirzel.

Halle, Morris. 1953. The German conjugation. Word 9. 45-53.

Haspelmath, Martin. 1993. More on the typology of inchoative/causative verb alternations. In Comrie \& Polinsky (eds.) 1993, 87-120.

Haspelmath, Martin. 2008. Frequency vs. iconicity in explaining grammatical asymmetries. Cognitive Linguistics 19. 1-33.

Heidinger, Steffen. 2014. The persistence of labile verbs in the French causative-anticausative alternation. Linguistics 52. 1003-1024.

Hyman, Larry M. \& William R. Leben. 2000. Suprasegmental processes. In Geert Booij, Christian Lehmann \& Joachim Mugdan (eds.), A handbook on inflection and word-formation, 587-594. Berlin: De Gruyter.

Kaufmann, Ingrid. 2007. Middle voice. Lingua 117. 1677-1714.

Koontz-Garboden, Andrew. 2009. Anticausativization. Natural Language \& Linguistic Theory 27. 77-138.

Kühnhold, Ingeburg \& Hans Wellmann. 1973. Deutsche Wortbildung: Typen und Tendenzen in der Gegenwartssprache. Erster Hauptteil: Das Verb. Düsseldorf: Pädagogischer Verlag Schwann.

Kulikov, Leonid. 2009. Valency-changing categories in Indo-Aryan and Indo-European: A diachronic typological portrait of Vedic Sanskrit. In Anju Saxena \& Åke Viberg (eds.), 
Multilingualism: Proceedings of the 23rd Scandinavian Conference of Linguistics (Studia Linguistica Upsaliensia 8), 75-92. Uppsala: Uppsala universitet. http://uu.diva-portal.org/ smash/record.jsf?searchld $=1 \&$ pid $=$ diva2\%3A275878\&dswid $=6784$

Lahiri, Aditi. 1982. Theoretical implications of analogical change: Evidence from Germanic languages. Providence, RI: Brown University doctoral dissertation.

Lahiri, Aditi. 2000. Hierarchical restructuring in the creation of verbal morphology in Bengali and Germanic. In Aditi Lahiri (ed.), Analogy, levelling and markedness, 71-123. Berlin: Mouton de Gruyter.

Lahiri, Aditi \& Vincent Evers. 1991. Palatalization and coronality. In Carol Paradis \& JeanFrançois Prunet (eds.), The special status of coronals (Phonetics and phonology 2), 79-100. New York: Academic Press.

Lahiri, Aditi \& Henning Reetz. 2002. Underspecified recognition. In Carlos Gussenhoven \& Natasha Warner (eds.), Laboratory Phonology 7, 637-676. Berlin: Mouton de Gruyter.

Lahiri, Aditi \& Henning Reetz. 2010. Distinctive features: Phonological underspecification in representation and processing. Journal of Phonetics 38. 44-59.

Levin, Beth \& Malka Rappaport Hovav. 1995. Unaccusativity: At the syntax-lexical semantics interface. Cambridge, MA: MIT Press.

Luraghi, Silvia. 2012. Basic valency orientation and the middle voice in Hittite. Studies in Language 36. 1-32.

Meinzer, Marcus, Aditi Lahiri, Tobias Flaisch, Ronny Hannemann \& Carsten Eulitz. 2009. Opaque for the reader but transparent for the brain: Neural signatures of morphological complexity. Neuropsychologia 47. 1964-1971.

Narrog, Heiko. 2009. Synchrony and diachrony in transitivity pairs. Paper read at the 8 th Biennial Conference of the Association for Linguistic Typology (ALT 8), University of California, Berkeley.

Nedjalkov, Vladimir P. 1969. Nekotorye verojatnostnye universalii v glagol'nom slovoobrazovanii. [Some probabilistic universals of verbal derivation.] In Igor' F. Vardul' (ed.), Jazykovye universalii i lingvističeskaja tipologija, 106-114. Moskva: Nauka.

Newman, John (ed.). 2009. The linguistics of eating and drinking. Amsterdam: Benjamins.

Nichols, Johanna. 1982. Ingush transitivization and detransitivization. Berkeley Linguistics Society 8. 445-462.

Nichols, Johanna. 1993. Transitive and causative in the Slavic lexicon: Evidence from Russian. In Comrie \& Polinsky (eds.) 1993, 69-86.

Nichols, Johanna, David A. Peterson, \& Jonathan Barnes. 2004. Transitivizing and detransitivizing languages. Linguistic Typology 8. 149-211.

Ottosson, Kjartan. 2013. The anticausative and related categories in the Old Germanic languages. In Folke Josephson \& Ingmar Söhrman (eds.), Diachronic and typological perspectives on verbs, 329-382. Amsterdam: Benjamins.

Paul, Hermann. 1917. Deutsche Grammatik, Band 2, Teil 3: Flexionslehre. Halle/Saale: Niemeyer.

Plank, Frans. 1984. Verbs and objects in semantic agreement: Minor differences between English and German that might suggest a major one. Journal of Semantics 3. 305-360.

Plank, Frans. 1985. On the reapplication of morphological rules after phonological rules and other resolutions of functional conflicts between morphology and phonology. Linguistics 23. 45-82.

Plank, Frans. 2009. The direction of derivation: How random!/? Paper read at the conference "Universals and Typology in Word-Formation”, Košice, 16-18 August 2009. 
Raven, Frithjof. 1963/1967. Die schwachen Verben des Althochdeutschen. 2 vols. Gießen: Schmitz.

Riecke, Jörg. 1996. Die schwachen jan-Verben des Althochdeutschen: Ein Gliederungsversuch. Göttingen: Vandenhoeck \& Ruprecht.

Rix, Helmut, with Martin Kümmel, Thomas Zehnder, Reiner Lipp, Brigitte Schirmer et al. 1998. Lexikon der indogermanischen Verben: Die Wurzeln und ihre Primärstammbildungen. Wiesbaden: Reichert.

Scharinger, Mathias. 2002. Dual difficulties? Lexical access and German irregular verbs within a featurally underspecified lexicon. Konstanz: Universität Konstanz MA thesis.

Scharinger, Mathias, Henning Reetz \& Aditi Lahiri. 2009. Levels of regularity in inflected word form processing. The Mental Lexicon 4. 77-114.

Schwerdt, Judith. 2008. Morphosemantik der schwachen Verben im Ostgermanischen und Kontinentalwestgermanischen. Frankfurt am Main: Lang.

Seebold, Elmar. 1970. Vergleichendes und etymologisches Wörterbuch der germanischen starken Verben. Den Haag: Mouton.

Spagnol, Michael. 2011. A tale of two morphologies: Verb structure and argument alternations in Maltese. Konstanz: Universität Konstanz doctoral dissertation.

Talmy, Leonard. 2000. Toward a cognitive semantics, Vol. 2: Typology and process in concept structuring. Cambridge, MA: MIT Press.

van Gelderen, Elly. 2011. Valency changes in the history of English. Journal of Historical Linguistics 1. 106-143.

Van Valin, Robert D., Jr. 2006. Some universals of verb semantics. In Ricardo Mairal \& Juana Gil (eds.), Linguistic universals, 155-178. Cambridge: Cambridge University Press.

Winteler, Jost. 1876. Die Kerenzer Mundart des Kantons Glarus in ihren Grundzügen dargestellt. Leipzig: Winter. 